\title{
Are beds in shelf carbonates millennial-scale cycles? An example from the mid-Carboniferous of northern England......
}

\author{
Maurice E. Tucker*, James Gallagher, Melanie J. Leng ${ }^{+}$ \\ Department of Earth Sciences, Durham University, Durham, DH1 3LE, UK \\ + NERC Isotope Geosciences Laboratory, British Geological Survey, Keyworth, \\ Nottingham, NG12 5GG and School of Geography, University of Nottingham, \\ Nottingham, NG7 2RD
}

\begin{abstract}
The mid-Carboniferous strata of northern England are characterised by mixed clastic-carbonate cycles (Yoredale cyclothems), attributed here to the short eccentricity Milankovitch rhythm. In a typical cycle, transgressive normal-marine shelf carbonates are succeeded by marine shales, then highstand prodelta mudstones and delta front-delta top sandstones with local coals. A detailed study of one cycle, the Great Limestone Cyclothem of the northern Pennines (Alston Block), reveals that within the transgressive carbonates, the beds, averaging $75 \mathrm{~cm}$ in thickness and defined by mm-shale partings or cm-mudrock layers, form two thinning-upward to thickening-upward bed-sets. Individual beds and the bed-sets can be correlated across the region. Oxygen isotope and strontium trace element data also reveal patterns of increasing and decreasing values through the limestone, which broadly correspond to the bed-thickness cycles.

The beds are interpreted as millennial-scale cycles, the result of highfrequency, arid-humid climatic fluctuations. The bed-sets are interpreted as the response to a longer term arid-humid climate and sea-level cycle, driven by the precession rhythm.

It is postulated that millennial-scale climatic changes, which are a well-known feature of the Quaternary and are here inferred for the Carboniferous, were responsible for the deposition of the beds that are a characteristic feature of many marine sedimentary successions in the geological record. The most likely over-riding control is fluctuations in solar output.
\end{abstract}

Keywords: Beds, Carboniferous, Yoredale cyclothems, Northern England, millennialscale cycles, solar forcing, Milankovitch rhythms

Corresponding author:

E-mail: m.e.tucker@durham.ac.uk 


\section{Introduction}

There is a large and rapidly growing literature on sub-Milankovitch, millennial-scale cyclicity recorded from Quaternary strata (e.g., Clark et al., 1999; Sarntheim et al., 2002). The mechanisms involved include: rapid warming/cooling for Dansgaard-Oeschger (D-O) events, Bond cycles attributed to oceanic-atmospheric circulation and high-frequency climate changes, and the shedding of ice-rafted debris (Heinrich events) in the North Atlantic, controlled by ice-sheet dynamics. Spectral analysis of Greenland ice cores has revealed millennial-scale periodicities in $\delta^{18} \mathrm{O}$, related to changes in climate and / or solar insolation. Centennial and millennial periodicities have been recorded in the aragonite content of upper-slope carbonates of the Bahamas (Roth and Reijmer, 2005), and sub-orbital sea-level fluctuations are also being inferred too, from Quaternary U-Th coral age data (Thompson and Goldstein, 2005).

Shelf and slope carbonate environments in the more distant past can also be expected to have been affected by sub-orbital rhythms resulting from millennial-scale fluctuations in solar output, climate change, and/or oceanic-atmospheric interactions, and these would have caused changes in depositional conditions, one way or another. However, there have been few descriptions of such high-frequency cycles in the stratigraphic record; or is it simply that they have been overlooked - that we have not been able to see the wood for the trees as it were? Where are the millennial-scale cycles in the stratigraphic record? Were they removed by erosion or bioturbation? Are storm events too frequent for them to be preserved? It is suggested here that the beds of the sedimentary record, well at least some of them, are the product of these highfrequency climate or environmental changes.

Millennial-scale cycles in sedimentary rocks have been reported from evaporitic and lacustrine successions (Anderson, 1982) and in particular from basinal facies (Elrick and Hinnov, 1996, 2007). However, many rhythmites in pelagic carbonate facies have been interpreted as precession driven (e.g., Schwarzacher 1993; Claps and Masetti 1994). The expression of the cyclicity is generally in the rapid alternation of different facies or sediment mineralogies, with regular patterns in bed/lamina thickness; these are then shown to be on the millennial scale by some statistical approach or some form of dating. This paper is suggesting that millennial- 
scale climatic rhythms were a feature of past-times and that in many cases they are represented in the rock record in the form of the beds, the fundamental building block of the stratigraphic record.

This paper describes the limestone beds that are prominent in the midCarboniferous strata of northern England (and elsewhere) and interprets them in terms of millennial-scale climatic variations. It is postulated, likewise, that many other beds in the stratigraphic record are millennial-scale cycles.

\section{Cycles in the Mid-Carboniferous of Northern England}

\subsection{Geological Context}

The Carboniferous period was a time of developing glaciation in Gondwana. Perhaps the first glacial stage occurred in the latest Devonian, evidence from Brazil, but by the later early Carboniferous (Asbian stage) the glaciation was well established (Wright and Vanstone, 2001). The Carboniferous succession in most parts of the world is markedly cyclic, and this is usually attributed to glacioeustasy (see below). In Europe in the Lower Carboniferous this commonly involves carbonates, while in the Upper Carboniferous the cycles are more clastic, with the Coal Measure cyclothems of the Westphalian being classic examples.

In the UK, cycles are prominent throughout the Carboniferous (George et al., 1976; Ramsbottom, 1973) and in northern England, in the mid-Viséan through Namurian (Liddesdale and Alston Groups, formerly the Carboniferous Limestone Group, see Table 1). They are typically of mixed clastic - carbonate facies, referred to as Yoredale cyclothems (Johnson, 1984) or Yoredale cycles (Tucker, 2003a). The Yoredale cycles were deposited over an area of some $10,000 \mathrm{~km}^{2}$ from north Yorkshire to southern Scotland (Fig. 1; Holliday et al., 1975), indicating that this region was effectively an epeiric platform. There were, however, areas of greater (basins) and lesser (blocks) subsidence, from south to north: the Central Pennine Basin, Askrigg Block, Stainmore Basin, Alston Block, Northumberland Basin, Cheviot / Southern Uplands Block and Tweed Basin (Fig. 1, Johnson, 1984). Thus there are differences in thickness across the region, but almost no differences in facies, except for the Central Pennine Basin which was a real deep-water basin. 
Clastic supply was dominantly from the north, so that broadly there is less clastic and more carbonate sediment in a southerly direction across the area.

The Yoredale cycles vary in thickness from around 5 metres to 50 metres. They generally consist of a lower carbonate part, up to 30 metres thick, overlain by a clastic section (Figs 2,3). In some cases the cycles are capped by a thin coal seam. Rarely an incised valley filled with coarse clastics cuts down into the cycle top, even nearly reaching the limestone (Figs 2, 3, 4, e.g., the Allercleugh channel-fill, Hodge and Dunham, 1991). The clastics are broadly deltaic, shallowing-upward, coarseningupward units (Fig. 4), although locally with shoreline or marine sand-bar facies (Leeder and Strudwick, 1987; Tucker, 2003a; Tucker et al., 2003). Towards the top of some thicker Yoredale cycles, much thinner (metre-scale), coarsening-upward 'minor' cycles are present in the clastics.

One particular Yoredale cycle, the Great Limestone Cyclothem, is being studied in detail in terms of facies, petrography, diagenesis and geochemistry (Gallagher, PhD thesis). It is the results of a study of the Great Limestone itself that are reported here. This cyclothem is in the basal Namurian, in the Pendleian stage (Table 1), and reaches 60 metres in thickness.

\subsection{Cycle stratigraphy and duration of cycles}

The cyclicity which so dominates Carboniferous sedimentary successions was largely produced by glacioeustatic changes in sea-level as a result of orbital forcing and variations in solar insolation (e.g. Veevers and Powell, 1987; Wright and Vanstone, 2001). Notwithstanding the dominance of orbital forcing, there will locally have been tectonic and sedimentary controls on deposition too. The Milankovitch rhythms for the Carboniferous are thought to have been 21 and $17 \mathrm{kyr}$ for precession (now 23 and 19 kyr), 34 kyr for obliquity (now 42 kyr)(Maynard and Leeder, 1992), and $112 \mathrm{kyr}$ and $413 \mathrm{kyr}$ for short and long eccentricity (as now, no change through the Phanerozoic).

There have been numerous papers discussing the periodicity of Carboniferous cycles in Europe and North America. Walkden (1987) suggested 260/360 kyr for Asbian cycles and 500 kyr for Brigantian cycles in Derbyshire. Maynard and Leeder (1992) calculated $120 \mathrm{kyr}$ for Namurian/Westphalian cyclothems in northern England. Ross and Ross (1987) gave a figure of $390 \mathrm{kyr}$ for Desmoinesian cycles in the 
southwest US, and Heckel (1986) 235/400 kyr for Mid-Pennsylvanian, mid-USA, cycles. Goldhammer et al. (1994) derived a figure of 230-385 kyr for the duration of Mid-Pennsylvanian cycles in the Paradox Basin, USA, but, accepting an orbital frequency control, then suggested that the cycles were actually either $400 \mathrm{kyr}$ (long eccentricity) $4^{\text {th }}$-order parasequences with $5^{\text {th }}$-order minor cycles of obliquity ( $34 \mathrm{kyr}$ ), or, $100 \mathrm{kyr}$ (short eccentricity) parasequences with $20 \mathrm{kyr}$ (precession) minor cycles. Horbury (1989) called upon short eccentricity to explain Asbian cycles in Cumbria, UK, and Smith and Read (2000, 2001) opted for a long-eccentricity control on Brigantian cycles in the US. Wright and Vanstone (2001) invoked short eccentricity to explain Asbian cycles in South Wales, with the possibility of the obliquity rhythm for early Asbian cycles.

With the Yoredale cycles in northern England, there are at least 70 cycles in the Asbian, Brigantian and Pendleian stages, a period of around 12 m.y. On a straight division, each cycle had a duration in the order 170 kyr. However, it is very unlikely that all the rhythms of sea-level change were preserved in the rock record; there would have been some, even many, missed beats (Hardie, 1986). Thus, actual duration of a cycle would be much less than the $170 \mathrm{kyr}$ figure; this implicates the short eccentricity rhythm

It is well known that orbital rhythms do vary in their intensity through time (Hardie, 1986; Gale, 1998), and, in addition, one rhythm is often modulated by a lower frequency rhythm. This is well seen in the short eccentricity rhythm which is strongly affected by the variations in intensity of the long eccentricity rhythm. The effect of precession also varies through time too, related to eccentricity. The result of this is that different amounts of accommodation space may be generated for each rhythm, so leading to strong variations in cycle thickness; in some cases composite cycles would be generated.

Taking all these factors into consideration, the most likely control on deposition of the Yoredale cycles would have been the short eccentricity rhythm (112 kyr). The variations in intensity of the Milankovitch rhythms through time also affect climate of course (temperature, humidity, aridity), not just sea-level. However, with an orbital-forcing control, these variations, as with sea-level, are likely to be regular, rather than random or irregular.

\subsection{Sequence stratigraphic interpretation of Yoredale cycles}


The Yoredale cycles show all the features of $3^{\text {rd }}$-order sequences (Tucker et al., 2003). The limestones constitute the lower parts of the Yoredale cycles and represent the transgressive systems tracts (TST)(Figs 2, 3, 5). The passage up into the overlying mudrocks is equivalent to the maximum flooding. Fossils are still present, pyrite frequently too. The succeeding coarsening-upward, shallowing-upward deltaic facies represent the highstand systems tracts (HST), and the thin coals and palaeosoils at the top of a typical cycle are the late HST/FS-LS/early TST. The incised-valley fills down-cutting into the HST facies represent the falling-stage (FSST) and lowstand (LST) systems tracts, of fluvial through estuarine facies, then succeeded by transgressive carbonates of the next sequence.

The Carboniferous was an icehouse time so that sea-level changes were amplified compared with greenhouse times. The duration of the Yoredale cycles as suggested here, $112 \mathrm{kyr}$, is fourth order in the hierarchy of sea-level change (Tucker, 1993). The Yoredale cycles are thus fourth-order high-frequency sequences. They are not parasequences in themselves, since they show all the systems tracts of sequences; however, any constituent higher-frequency cycles within them could be referred to as parasequences.

\section{Yoredale limestone sedimentology}

\subsection{Limestone composition}

Yoredale limestones vary from bioclastic lime mudstones to grainstones, but the majority are wackestones-packstones (Figs 6, 7). $\mathrm{CaCO}_{3}$ content is mostly around 90-97\%). The fine-grained matrix to the limestones is mostly a micrite to microsparite (from patchy neomorphism), although a peloidal structure is frequently seen in thinner sections. The majority of the bioclasts are less than a few $\mathrm{mm}$ in size and consist of brachiopod and bivalve shell fragments and foraminifera, as well as crinoidal, bryozoan and calcareous algal material (Figs 6,7). Other less common fossil debris includes that of gastropods, nautiloids, serpulids, ostracods and trilobites. Larger, often whole fossils include the corals (rugose and tabulate) and productid and spiriferid brachiopods (Fig. 8). There is also significant bioclastic hash, probably derived from the comminution of skeletal material by scavenging organisms. 
Although many of the fossils occur throughout the limestones, certain fossils define biostromes. In the Great Limestone, for example, there are biostromes of the coral, Dibunophyllum (Fig. 9) which forms the famous Frosterley 'marble' of Weardale, used as columns in the $11^{\text {th }}$-Century (Norman) Durham Cathedral. There are also lenses and beds of Chaetetes (a sponge), and the brachiopod Gigantoproductus, often seen in growth position (Fig. 10)(Johnson, 1958; Fairburn, 1999). There are also other quite rare local accumulations of specific fossils, such as beds of Girvanella nodules, Sphaerocodium, and spiriferids.

The composition of the limestones has been studied in detail by JG with around 150 thin-sections taken at $\sim 15 \mathrm{~cm}$ intervals through the Great Limestone from the locality of Hudeshope Beck, near Middleton in Teesdale. This is the locality where samples for isotope and trace element analyses were collected. The petrographic examination of the thin-sections indicates that there is no discernible systematic change in the composition of the microfacies up through the Great Limestone. There is no observable change in the proportions of the various bioclastic elements; all samples are similar - bioclastic wackestones-packstones with a range of skeletal fragments (Figs 6, 7). There is no indication of any gradual changes through the succession, nor of any changes across a bed either. It may be that with more detailed study of the foraminifera some pattern may emerge, but to all intents and purposes, it seems clear that the limestone beds were all deposited under similar conditions, although, presumably specific local conditions allowed the coralbrachiopod biostromes to form.

On the whole there is little evidence of compaction within the limestones (as can be seen in Figs 6,7). Some elongate shell fragments may be broken as a result of mechanical compaction, and pressure dissolution is only significant adjacent to shale partings (see Section 4.1).

\subsection{Sedimentary structures in the limestones}

Within the Yoredale limestones of the Alston Block there are locally sedimentary structures indicating current activity. Bioclasts are commonly concentrated into lenses, 10-30 cm across, several $\mathrm{cm}$ in thickness. There may be some crude lamination defined by the grain-size of the fossil fragments. Crosslamination or cross-bedding is only very rarely seen within the beds. Larger fossils do 
show preferred orientations at some localities. Fairburn (1999) has deduced palaeocurrent patterns from oriented corals, crinoids and brachiopod shells.

There is abundant evidence of bioturbation. Polished surfaces do show areas of more to less densely packed coarse bioclastic material, usually $0.5-3 \mathrm{~cm}$ in diameter. These are interpreted as cross-sections through burrows. Upon the bedding planes there can often be seen burrows, simple straight to curved structures, 0.5 to 2 $\mathrm{cm}$ across, and up to $10 \mathrm{~cm}$ in length. These can be attributed to the general group Planolites. The trace fossil Zoophycos does occur on some bedding planes, with the distinctive concentric burrow system reaching $15 \mathrm{~cm}$ across.

\subsection{Depth of deposition}

The Yoredale limestones are interpreted as the result of deposition in the outer shoreface/transition to offshore environment, where water depths would have been in the range of 5-30 metres. The sedimentary structures, concentrations of bioclasts and preferred orientations of elongate fossils, are consistent with some storm activity, which would be expected at these water depths. The general absence of HCS and well-developed cross-stratification support the interpreted depths of deposition on this epeiric platform. Such structures have been described from mid-Carboniferous ramp carbonates of South Wales (Wright, 1986). The biogenic structures are also consistent with water depths to a few 10 s of metres.

These Yoredale limestones are typical mid-shelf or mid-ramp limestones deposited in shallow to moderate water depths where sediments were occasionally affected by storms. In these slightly deeper-water environments this might be on a frequency of decades to centuries, if one thinks of the recurrence interval of hurricanes in the Caribbean where one particular location may be affected every 100 years or so.

\section{Beds in the Mid-Carboniferous limestones}

\subsection{The nature of the beds and shale partings}

The mid-Carboniferous shelf limestones of northern England have a welldeveloped bedding (Figs 4, 11). The beds in the Yoredale limestones vary in thickness 
from a few $\mathrm{cm}$ to a metre or more, but generally they are in the range 30 to $100 \mathrm{~cm}$. The average thickness of beds in the Great limestone is $75 \mathrm{~cm}$.

The bedding is defined by thin shale partings (1-5 mm in thickness) to thin mudrock interbeds (generally less than $2 \mathrm{~cm}$ thick) (Fig. 11). There may be a transition from the purer limestone to the mudrock parting over a few mm, but normally the contact is sharp. The bedding planes are generally planar to undulating, and black from attached dark shale. In the upper 5 metres, the partings become a little thicker, reaching 2-5 cm. This topmost part of the Great Limestone with a little more mudrock is known as the Tumbler Beds (Fig. 12), and is the transition into the overlying marine mudrock.

The bedding planes have commonly been affected by pressure dissolution. Indeed in some cases the bedding plane is a clear pressure dissolution seam with some anastomosing and dark clayey insoluble residue within the seams. There may also be stylolites parallel to the bedding, sutured and generally with less than $2 \mathrm{~cm}$ of relief along the surface. The distribution of these is shown in Fig. 12.

The issue of pressure dissolution enhancing bedding planes, as well as creating them, has been addressed by Simpson (1985) and Bathurst (1987). Both of these studies actually involved Carboniferous limestones from the UK, and so the conclusions presented there are directly applicable to the rocks discussed here, namely that bedding planes were commonly enhanced by pressure dissolution, and indeed in some cases formed in that way.

\subsection{Bed continuity}

It was realised very early on, in the $18^{\text {th }}$ Century if not earlier, during the search for lead-zinc sulphide minerals and specific beds of fossils (the Frosterley 'marble'), that individual beds within the Great Limestone were distinctive and so could be recognised around the Pennine Hills. Each bed, or post as it was called, was given a specific name by the miners and quarrymen (see Fig. 12). These beds are remarkably continuous across the Alston Block and into the Northumberland Basin. Fairburn $(1978,1980)$ described this startling continuity, which clearly shows that uniform depositional conditions were laterally very extensive. To the south, across the Stainmore Basin and on to the Askrigg Block, the continuity of beds is not so clear, as 
the mixed clastic-carbonate cycles pass southwards into carbonate-dominated cycles (Fairburn 2001).

\subsection{Bed-thickness patterns}

Measuring the thickness of beds in the Great Limestone shows that the bed thickness is not random. Within the limestones there is a clear pattern of beds thinning and thickening upwards (Fig. 13). And if this is not remarkable enough, the cycles in bed-thickness, the bed-sets, are present in all the localities measured in Weardale abd Teesdale (Fig. 14), showing that it is a genuine pattern, widely developed. Looking at the pattern, two cycles of bed-thickness variation are clearly seen, each consisting of thinning-upward then thickening-upward beds. Each bed-set consists of around 8-10 beds.

\subsection{Geochemical patterns within the Great Limestone}

Numerous geochemical analyses have been made of the Great Limestone which will be the subject of a detailed paper elsewhere. However, it is useful to note here that there are patterns within the data, notably of the oxygen isotope $\delta^{18} \mathrm{O}$ and the trace element strontium. Of particular interest in terms of the origin of the beds and bed-sets is the oxygen isotope data. $\delta^{18} \mathrm{O}$ values of 142 samples taken at $\sim 15 \mathrm{~cm}$ intervals through the Great Limestone are presented in Table 2 and shown stratigraphically through the limestone in Fig. 12. There is a lot of noise in the data, as to be expected, but there is a general pattern of increasingly negative and decreasingly negative $\delta^{18} \mathrm{O}$ (see Fig. 15) which broadly correlates to the thinning-up and thickening-up of the beds respectively; i.e. there is a cyclic pattern in the $\delta^{18} \mathrm{O}$ data which correlates with the cyclic pattern in bed thickness: more negative trends in $\delta^{18} \mathrm{O}$ where beds are thinner; less negative $\delta^{18} \mathrm{O}$ values where beds are thicker (see Fig. 15).

In addition, there is a pattern in the $\delta^{18} \mathrm{O}$ (and $\delta^{13} \mathrm{C}$ ) data for some individual beds: namely for $\delta^{18} \mathrm{O}$ values to be more negative towards the margins of a bed, and less negative within the central part of the bed (Fig. 16). For $\delta^{13} \mathrm{C}$ values they are less positive at the margins and more positive in the centre of a bed.

The strontium trace element data (70 samples) also show a pattern of increasing and decreasing values, which broadly correspond to the patterns in the bed 
thickness. Here the values of $\mathrm{Sr}$ are higher where the beds are thicker, and lower where beds are thinner (Fig. 17)

That these patterns in the geochemical signals, to a greater or lesser extent, follow the patterns in the bed thickness is truly remarkable. It lends support to the interpretation that the patterns seen in the bed thickness are reflecting some overall external control on deposition. Some of the trends in the isotope data could, of course, be interpreted in terms of diagenesis (to be fully discussed elsewhere, also see Section $6.3)$.

\section{Duration of beds and bed-sets}

If it is accepted, as argued in Section 2.2, that the Yoredale cycles as a whole are formed by the short eccentricity astronomic rhythm, which in the Carboniferous was $112 \mathrm{kyr}$, then there is the likelihood that the bed-sets are the product of a higherfrequency orbital rhythm. This would be either precession or obliquity.

The clastics in the upper part of the Yoredale cycles are broadly deltaic as noted earlier. In the Great Limestone Cyclothem, 4 minor cycles can be recognised in the clastics; each consists of a thin (1-5 m thick) coarsening-upward unit of mudrock to fine to coarse sandstone, locally with coal (Fig. 18). Thus with 4 minor cycles in the clastics and the 2 bed-sets in the carbonates, there are 6 high-frequency cycles within the one Great Limestone clastic-carbonate Yoredale cyclothem. This suggests that the minor cycles are the order of $\sim 18,000$ years in duration; this is within the timeframe of the precession rhythm (and not obliquity). If this is accepted, then with around 10-12 beds in a bed-set, the duration of the Yoredale limestone beds themselves is the order of 1500-2000 years; that is millennial scale (see Fig. 5).

The fact that the beds are part of a longer-term package of thinning and thickening upwards suggests they are actually cycles themselves, with their deposition controlled by subtle changes in the environment, of one sort or another.

If the Yoredale limestone beds are millennial scale, then the sedimentation rate would have been in the range 0.1 to $0.75 \mathrm{~m} 1000 \mathrm{yr}^{-1}$, with an average of $0.37 \mathrm{~m} 1000$ $\mathrm{yr}^{-1}$. This figure is very reasonable compared with modern sedimentation rates, which in a shelf environment could well be expected to be many $10 \mathrm{~s}$ of $\mathrm{cm} 1000 \mathrm{yr}^{-1}$ (Schlager, 2003). It is worth noting that Wright (1994) has suggested higher 
sedimentation rates for shelf/mid-ramp as opposed to shoreline/inner-ramp environments for early Carboniferous times, related to nutrient supply.

If, on the other hand, the Yoredale cycles were to be interpreted as the result of the long eccentricity rhythm ( 413 kyr), as suggested by Smith and Read (2000) for example, then the 6 minor cycles within the Great Limestone Cyclothem would have a duration of nearly $70 \mathrm{kyr}$; this figure does not fit comfortably with the orbital rhythms. The limestone beds themselves then would be the order of 6-7000 yr, again not a readily identifiable rhythm. The sedimentation rate would be reduced to an average of $0.11 \mathrm{~m} 1000 \mathrm{yr}^{-1}$; this is still not unreasonable but getting rather low.

Thus it is concluded that, on balance, the limestone beds are most sensibly interpreted as millennial scale ( 1500-2000 yrs), the limestone bed-sets and clastic minor cycles as the result of the precession rhythm $(\sim 18,000 \mathrm{yrs})$, and the Yoredale cyclothem itself as short eccentricity (see Fig. 5). It is worth noting that a packaging or bundling of the Yoredale cyclothems themselves can be observed in Fischer plots of the whole Alston-Stainmore Group succession (Tucker et al., 2003). This could be a reflection of the long eccentricity rhythm.

\section{Discussion and interpretations}

The data presented here suggest that the limestone beds of the midCarboniferous of northern England were the result of millennial-scale variations in factors which control deposition. These factors then varied systematically through time, generating the bed-sets. As interpreted above in Section 5, the bed-sets in the Great Limestone were the result of the effects of the precession astronomic rhythm, with the Great Limestone Cyclothem as a whole a response to the short eccentricity rhythm (Fig. 5).

There are many factors that can have an influence on carbonate deposition: sea-level change, water depth, nutrient supply, oxygenation, current strength, turbidity and clastic influx, freshwater-riverine influx, rainfall, aridity-humidity (dry-wet) climate cycles, temperature, etc, etc, and many of these are interrelated of course (Tucker and Wright, 1990; Schlager, 2003, 2005). The degree of change will have depended on the icehouse-greenhouse state of the Earth at the time, the role of the orbital forcing parameters and their interaction, the palaeolatitude, and the variation in solar output. 
There are two issues for the formation of the Yoredale limestone beds: the origin of the bed-sets, that is the thinning-upward to thickening-upward bed pattern, and the origin of the individual beds themselves.

\subsection{Origin of bed-sets}

As noted above deposition of the bed-sets is here related to the precession rhythm. The well-organised nature of the bed-thickness trends can only be interpreted in terms of allocyclic controls on deposition. It cannot result from a purely sedimentary control (autocyclicity), such as progradation of sediment shoals for example, which would give random and irregular bed-thickness patterns. The bed-sets of thinning-upward to thickening-upward beds have to be the result of some regularly increasing-decreasing changing parameter(s).

The source of carbonate sediment on a platform is the result of both in-situ carbonate production and the influx of carbonate from a shallower-water factory, brought there by waves, tidal currents and storms. With deposition of the Yoredale limestones taking place at around 5-30 metres water depth, both in-situ carbonate accumulation and influxes of carbonate are likely. However, since the individual beds of the Great Limestone are correlatable over the whole platform, and the thickness variations up through the beds are the same everywhere, it would seem likely that the same depositional conditions were operating over the whole platform. In addition, the composition of the limestones is much the same over the platform. Thus, redistribution of carbonate sediment on a large-scale is unlikely, as this would have led to a random lateral thickening and thinning of individual beds, and the regular pattern of bed-thickness changes seen across the platform would not have been generated.

There is evidence of storm reworking within the beds, as noted above, but no evidence for the wholesale introduction of large quantities of sediment from a shallower-water source area, as would be provided, for example, by the presence of graded beds ('tempestites') of shallow-water bioclastic material. In fact, there are no very shallow-water carbonate facies (such as tidal-flat limestones) present on the platform. This suggests that the flooding of the platform, after deposition of the siliciclastic delta-top / swamp facies at the top of the previous cycle, was very rapid indeed, so that moderately deep conditions were quickly and uniformly established 
across the region, and then that these conditions more or less lasted for the duration of carbonate deposition. In the case of the Great Limestone this was the order of $40 \mathrm{kyr}$. This does suggest that the platform was more of an epeiric-sea, rather than a type of carbonate ramp (Tucker and Wright, 1990). With some Yoredale cycles, there is a basal marine mudrock or sandstone (up to $20 \mathrm{~cm}$ thick), derived from reworking of the top of the underlying cyclothem.

During deposition of the Great Limestone, there was clearly plenty of accommodation space. However, this was not being filled by the carbonate sediments; deposition was all 'mid-shelf' for the limestone beds. There was no shallowing upward to peritidal carbonate facies; the first overlying siliciclastics are marine shales then prodelta mudstones. The incoming of this terrigenous material terminated carbonate production and then deposition progressively became non-marine. Thus, bed thickness itself and bed-thickness variation in the bed-sets are not due to systematic changes in accommodation space (i.e. relative sea-level changes) per se, as is the case for peritidal parasequences of many carbonate platform interiors for example, where they usually aggrade to sea-level (e.g. Tucker and Wright, 1990; Lehrmann and Goldhammer, 1999).

Sea-level changes inducing depth changes could have affected carbonate production of course, with higher rates at shallower depths from a sea-level fall, giving rise to thicker beds, and lower rates in deeper water generating the thinner beds (Fig. 19). The shallowing could have lead to higher productivity through increased nutrients from continental run-off and/or warmer water in the shallower seas and/or higher current activity and improved circulation / oxygenation. The thinning-upward then thickening-upward bed-thickness pattern in the bed-sets could therefore be the result of deepening up, then shallowing up, as a consequence of the precession rhythm driving sea-level change, causing variations in the factors governing carbonate precipitation as water depth changed. With a sea-level rise and deepening, beds would thin upwards, and with a sea-level fall and shallowing, beds would thicken upwards. It is well known that the precession rhythm does cause sea-level change through the variation in solar radiation reaching the Earth and the effect of this on the size of the polar ice-caps and ocean-water volume. The Great Limestone begins with thinning upward beds - forming the lower part of the first bed-set; this could be interpreted as indicating continued sea-level rise after the initial, rapid flooding of the platform. 
Another possibility, with or without sea-level change, is a climatic explanation of arid to humid (dry to wet) climate change, i.e. effectively changes in salinityturbidity, again driven by variations in solar insolation as a result of the precession rhythm (schematically shown in Fig. 19). During more arid times, less rainfall, normal to slightly hypersaline seawater and clearer, less turbid seas would have led to higher productivity and so the trend to thicker beds; by way of contrast, under more humid conditions, with increased rainfall, lowered seawater salinity, increased water turbidity and terrigenous clay influx, a trend towards thinner beds would have resulted from decreasing carbonate productivity.

A further possibility, again not necessarily connected with sea-level change, is an explanation based on temperature changes through the precession rhythm (Fig. 19), since that is a major control on carbonate productivity. In this case, higher temperatures would lead to increased carbonate productivity which would give the trend to thicker beds, whereas lower temperatures would lead to the trend towards thinner beds (Fig. 19).

\subsection{Origin of beds}

The individual beds, bioclastic packstone-wackestone separated by mm-shale partings to cm-mudrock layers, are interpreted here as cycles, the result of millennialscale rhythmic changes in environmental parameters. In the last decade, millennialscale variations in the Quaternary have been reported in temperature (Huls and Zahn, 2000), freshwater run-off and storminess (Noren et al., 2002), monsoon and ENSO activity (Moy et al., 2002; Gupta et al., 2003, Yancheva et al., 2007), terrigenous input to the sea (Arz et al., 1998) and sea-level change (Potter et al., 2004; Thompson and Goldstein, 2005). These could all have changed carbonate productivity and/or clay input to the seas. The ultimate control could be ocean-atmosphere interactions and/or changes in solar output (Haigh, 1996; Van Geel et al., 1999, Bond et al., 2001).

For a sea-level control on bed formation, carbonate deposition could have been interrupted or terminated by either a sea-level fall or sea-level rise (see Fig. 20), bringing an influx of clay into the environment to generate the shale partings and mudrock layers to define the beds. During a sea-level fall, one would expect increased mud input to the shelf through increased river activity and down-cutting into floodplains and coastal mudflats. During a sea-level rise, mud would be 
reworked from coastal mudflats in proximal areas. Sea-level changing depth and so carbonate productivity is also likely, as discussed above, for the origin of the bed-sets, with thickening-up beds indicating shallowing water. However, accepting higher carbonate productivity during lowering of sea-level and shallowing water, argues against clay input through sea-level fall. The input of clay and termination of carbonate deposition to form a bed would thus more likely have taken place through a sea-level rise.

An alternative explanation for the deposition of the beds is fluctuations in carbonate productivity through millennial-scale climate change, with or without selevel change, and with a constant but low supply of clay. Carbonate productivity could be increased through higher temperatures (Fig. 20), as is well known for corals and other organisms (Schlager, 2003), although only up to a certain point. Correspondingly, carbonate productivity could be lowered through reduced sea-water temperature, this then allowing a shale parting or mudstone layer to accumulate to define the bedding.

The individual beds could be the result of millennial-scale arid-humid climate cycles (Fig. 20). A change in climate to a more humid phase could lead to increased clay input from more river activity, to generate the shale partings. The influx of clay generating turbid water and increased freshwater runoff would both have a detrimental effect on carbonate productivity. Thus, it could be that the carbonates were deposited during times of a more arid climate, with humid pulses leading to the deposition of the clay interbeds. One would assume that the humid phases were shortlived, since the shale partings and mudrock layers are so thin; they could be horizons of condensation though, representing longer periods of time. In this scenario then, each unit of shale parting-limestone-shale parting would represent a humid-aridhumid climate cycle. The pattern of increasing-upward bed thickness would represent an increasingly arid time, but still with the millennial-scale sharp humid phases to produce the shale partings, and each thinning-upward bed pattern would represent a less arid period, but again still with the sharp humid pulses.

The epeiric-sea nature of the Yoredale platform, and its likely low tidal range, may well have resulted in poor mixing and stratification (Allison and Wright, 2005). During more humid times, a layer of fresh or brackish water may well have developed upon normal seawater. Variations in mixing would have affected carbonate productivity. 
During the mid-Carboniferous, northern England was located in the equatorial zone. In these regions, annual temperatures do not vary as much as in the subtropics, but there are significant changes in rainfall. On a longer time-frame, there may be important changes in rainfall, and an alternation of arid-humid climate cycles in low latitudes, as a result of movement of the intertropical convergence zone (ITZ). Millennial-scale migrations have been reported from the Quaternary (Rind, 1999; Gupta et al., 2003; Yancheva et al., 2007), related to changes in latitudinal temperature gradients. Variability of ENSO activity on a millennial scale has also been reported (Moy et al., 2002), and this would lead to substantial fluctuations in rainfall, and temperature too.

The problem of the origin of the beds being discussed here is similar to that for the marl-limestone rhythmicity frequently seen in basinal-pelagic successions (Gale, 1998; Elrick and Hinnov, 2007). Interpretations there have considered two endmember scenarios: fluctuating carbonate productivity against constant clay input (productivity cycles), and fluctuating clay input against constant carbonate precipitation (dilution cycles).

\subsection{Oxygen isotope data}

The $\delta^{18} \mathrm{O}$ data, which will be discussed in detail elsewhere, do help in the interpretation of the origin of the bed-sets and beds. The less negative $\delta^{18} \mathrm{O}$ values occur in the zones of thicker beds and within the central portions of the beds, whereas more negative $\delta^{18} \mathrm{O}$ values occur within zones of thinner beds and at bed margins (Fig. 19).

There are 3 simple explanations for the isotope trends:

1) The less negative values could indicate cooler waters, and the more negative values could indicate warmer waters (see Fig. 19, 20). As argued above, the bed/bed-set thickness patterns could be the result of temperature changes affecting carbonate productivity. However, for a temperature control, it was argued above that one would expect the thicker beds to be the result of warmer waters giving higher carbonate productivity; BUT, the zone of thicker beds generally has less negative $\delta^{18} \mathrm{O}$ values. It was also argued that for a temperature control on the beds themselves, warmer waters, giving higher carbonate productivity, would be expected for main portions of the beds, with cooler waters at the margins to allow the clay to be deposited; BUT the 
central parts of the beds have less negative $\delta^{18} \mathrm{O}$ values, the margins of the beds have the more negative values. Thus, the $\delta^{18} \mathrm{O}$ data do not support a simple temperature explanation for the beds or bed-sets.

2) The $\delta^{18} \mathrm{O}$ data could be interpreted instead in terms of changes in water salinity, less-marine to more-marine, as would be the case with arid-humid climate cycles. In this case the more negative $\delta^{18} \mathrm{O}$ values indicating less marine conditions coincides with zones of thinner beds, and bed margins, and so is consistent with more humid conditions reducing carbonate productivity, and the reverse: less negative values coinciding with thicker beds and bed centres is consistent with more marine conditions enhancing higher productivity.

3) The $\delta^{18} \mathrm{O}$ data could be interpreted in terms of increases and decreases in ice volume at the polar ice-caps (Fig. 19). In this scenario, more negative $\delta^{18} \mathrm{O}$ trends in marine carbonate would indicate less polar ice; less negative $\delta^{18} \mathrm{O}$ data would indicate more polar ice. Larger ice-caps would lead to lower sea-level; less ice would lead to higher sea-level. The less negative $\delta^{18} \mathrm{O}$ values within zones of thicker beds indicating lower sea-level, is consistent with arguments presented above for the origin of the thicker bed during lower sea-level, and for a sea-level/depth interpretation for the beds too.

One further explanation for the oxygen isotope data could be that it is largely diagenetic, the result of recrystallisation and burial cementation. However, although it is clear that oxygen isotope data have been reset, it is difficult to explain the stratigraphic trend of more and less negative $\delta^{18} \mathrm{O}$ coinciding with the bed thickness pattern as purely diagenetic. The $\delta^{18} \mathrm{O}$ data for the individual beds (Fig. 20) on the other hand, could well be diagenetic, with more burial cementation taking place at bed margins as a result of pressure dissolution there, giving the more negative $\delta^{18} \mathrm{O}$ values.

Thus, it is concluded that deposition of the beds in the Great Limestone is primarily controlled by high-frequency millennial-scale arid-humid climatic cycles and/or changes in water depth/sea-level, controlling carbonate productivity. The bedset and bed-thickness pattern is related to lower frequency arid-humid climate and sea-level change on a precession scale. Temperature changes are not directly implicated.

\subsection{Strontium data}


The strontium values for the limestone vary from a few 100 to a few 1000 ppm, but there is a broad pattern of higher values coinciding with thicker beds (Fig. 17). Strontium content in carbonates can be related to original aragonite content (Tucker and Wright, 1990), but could also reflect terrigenous input. However in this case the limestones are quite pure, more than $90 \% \mathrm{CaCO}_{3}$, often more than $95 \%$, so that the low terrigenous content is unlikely to have been sufficient to provide the $\mathrm{Sr}$ recorded. Variations in aragonitic bioclast content could provide an answer. The higher Sr content of thicker beds could indicate a higher proportion of aragonitic bivalves and gastropods originally. Their dissolution-replacement during early diagenesis may have released the Sr to early cements. Wright and Cherns (2004) have suggested early dissolution of aragonite as a feature of periods of calcite seas, like the Lower Carboniferous, and this would have lead to preferential preservation of calcitic fossils. A higher component of aragonitic bioclasts in the thicker beds could indicate more suitable conditions for these organisms and higher rates of carbonate productivity at these times.

\section{Beds as cycles in the sedimentary record}

Beds are a fundamental signature of sedimentary rocks. There are clearly many possible origins for beds (see Tucker, 2003b), but it is suggested here that if looked at closely, it would be found that many in the geological record are on the millennialscale and that there are thickness patterns which define bed-sets, so that they are actually cycles in themselves, and not in anyway random, as has generally been supposed. In addition, it should be noted that the beds in many parts of the geological record are actually defined by shale partings, as those described here; "mm-shale parting - decimetre-thick bed - mm-shale parting" is a motif of many depositional facies.

The preservation of beds will be most likely in the shallow to moderately deep marine environment, where the effects of storm waves and currents, and tidal currents, are minimal. In the inner shoreface and foreshore zones, well above fairweather wave-base, extensive reworking is likely to remove the millennial-scale signature. However, millennial-scale rhythms have been described from some nonmarine environments, notably evaporitic-lacustrine successions (Anderson, 1982). 
This shows that the millennial-scale signal is a global one and the issue is primarily a case of where will it be preserved.

In terms of preservation of millennial-scale beds in the marine shelf record, then this is most likely to be during transgressive periods, when increasing accommodation space allows sediments to be buried, so preserving more of the depositional record. In the Carboniferous case described here, the limestones are the transgressive systems tract of the high-frequency sequence, and with deposition being all shallow to moderate depth, the preservation potential of the beds and bed-sets is high.

Mid-shelf and mid to outer-ramp carbonates should be examined for their beds and bed-thickness patterns to test the validity of the arguments presented here, that bed-cycles are a feature of the rock record. The work of Badenas et al. (2005) on the Kimmeridgian mid to outer-ramp carbonates of northwestern Spain has shown that beds, around 5-10 in number, are a feature of metre-scale cycles interpreted as formed by the precession rhythm. In this case then, the beds of limestone, separated by shale partings, would have to be millennial scale.

In the carbonate platform interior, metre-scale shallowing-upward cycles (parasequences, $4^{\text {th }}-5^{\text {th }}$ order) are typical, with their thickness, facies, and even diagenesis, controlled by the nature of the third-order sea-level changes and icehousegreenhouse effects (Tucker, 1993). In many cases an explanation for the parasequences as a result of precession-scale ( 20,000 -year) sea-level changes has been proposed or accepted (reviewed in Tucker and Wright, 1990, Lehrmann and Goldhammer, 1999). However, frequently it is noted in passing that in addition to the shallowing-upward of the facies in a parasequence, there is an increase in bed thickness leading up to the exposure surface at the top of the cycle. For an example see Figure 21 of a parasequence from the Cambrian of the Argentine Precordillera (Gomez et al., 2007). Now this increasing bed-thickness cannot simply be the result of shallowing and decreasing accommodation. Why would the shale partings be there if this was so? It must again indicate a millennial-scale alternation of the parameters controlling deposition, and an increasing rate of carbonate production as the environment shallowed, interspersed with regular influxes of clay to define the beds. These beds are effectively cycles themselves, within the parasequence.

Recent work on the Triassic Latemar platform carbonates of the Dolomites, northern Italy, has thrown another spanner into the works. These classic metre-scale 
peritidal cycles have been shown to be sub-orbital in origin (Zühlke et al., 2003; Mundil et al., 2003), with a duration of 4000 years each, in contrast to earlier interpretations of a precession origin. In the context of this paper then, at least some high-frequency peritidal cycles are themselves on a millennial scale and their constituent beds will be millennial scale too, or centennial.

In Palaeozoic basinal successions, the work of Elrick and Hinnov (1996, 2007) has shown convincingly that rhythmically-bedded pelagic limestone-marl or chertlimestone couplets are of millennial scale. Many 100s of metres of these rhythmites occur in basins throughout the world and they are ascribed to climatic variations of arid-humid cycles controlling clay input and biogenic carbonate-silica productivity. Mawson and Tucker (2008) have described millennial-scale, metre-scale cycles of decreasing- and increasing-upward calciturbidite bed thickness from the Permian of NE England, which bundle into precession and eccentricity-driven thicker cycles.

Many of the arguments advanced in Elrick and Hinnov (2007) for the origin of the basinal rhythmites apply to the Carboniferous shallow-water limestone beds of this paper. Indeed, the final conclusion of Elrick and Hinnov (2007), that the ultimate control may well be millennial-scale fluctuations in solar output, recently being widely postulated for Quaternary climate change (Haigh, 1996; Van Geel et al., 1999; Bond et al., 2001), is supported by the authors of this paper.

\section{Conclusions}

This paper has presented evidence that the limestone beds in the mid-Carboniferous succession of northern England are actually millennial-scale cycles which are most likely produced by high-frequency arid-humid climatic fluctuations, with or without sea-level changes. It is accepted that this may be contentious but it is suggested that beds, the fundamental unit of the stratigraphic record, deserve closer attention. So, sedimentologists-stratigraphers, go out and look at the bedding in the whole range of sedimentary facies. Measure the bed thickness, look for patterns; analyse the rocks for isotopes and trace elements, look for patterns. There is much information to be gathered there which can be interpreted in terms of climate and sea-level change, and ultimately controlled, possibly, by variations in solar output.

\section{Acknowledgements}


We are grateful for fruitful discussions with Howard Armstrong and Bruce Malamud, and comments of reviewers. MET apologies to the missus for having to suffer the millennial cycles story for the last few years.

\section{References}

Allison. P.A., Wright, V.P., 2005. Switching off the carbonate factory: a-tidality stratification and brackish wedges in epeiric seas. Sedimentary Geology 179, 175184.

Anderson, R.Y., 1982. A long geoclimatic record from the Permian. Journal of Geophysical Research 87, 7285-7294.

Arz, H.W., Patzold, J., Wefer, G., 1998 Correlated millennial scale changes in surface hydrography and terrigenous sediment yield inferred from last-glacial marine deposits of northeast Brazil. Quaternary Research 50, 157-166.

Badenas, B., Aurell, M., Grocke, D.R., 2005. Facies analysis and correlation of highorder sequences in middle-outer ramp successions: variations in exported carbonate on basin-wide $\delta^{13} \mathrm{C}$ (Kimmeridgian, NE Spain). Sedimentology 52, 1253-1275.

Bathurst, R.G.C., 1987. Diagenetically-enhanced bedding in argillaceous platform limestones: stratified cementation and selective compaction. Sedimentology 34, 749778.

Bond, G., Kromer, B., Beer, J., Muscheler, R., Evans, M.N., Showers, W., Hoffmann, S., Lotti-Bond, R., Hajdas, I., Bonani, G., 2001. Persistent solar influence on North Atlantic climate during the Holocene. Science 294, 2130-2136.

Claps, M., Masetti, D., 1994. Milankovitch periodicities recorded in Cretaceous deepsea sequences from the Southern Alps (Northern Italy) In: de Boer, P.L. and Smith, DG. (Eds.). Orbital Forcing and Cyclic Sequences. International Association of Sedimentologists Special Publication 19, 99-108. 
Clark, P.U., Webb, P.S., Keigwin, L.D. (Eds) 1999. Mechanisms of Global Climate Change at Millennial Time Scales. Geophysical Monograph, American Geophysical Union, 112.

Elrick, M. \& Hinnov, L.A., 1996. Millennial-scale climate origins for stratification in Cambrian and Devonian deep-water rhythmites, western U.S.A. Palaeogeography Palaeoclimatology Palaeoecology 123, 353-372.

Elrick, M. \& Hinnov, L.A., 2007. Millennial-scale paleoclimate cycles recorded in widespread Palaeozoic deeper water rhythmites of North America. Palaeogeography Palaeoclimatology Palaeoecology 243, 348-372.

Fairburn, R.A., 1978. Lateral persistence of beds within the Great Limestone (Namurian, $E_{1}$ ) of Weardale. Proceedings Yorkshire Geological Society 41, 533-544.

Fairburn, R.A., 1980. The Great Limestone (Namurian) of south Northumberland. Proceedings Yorkshire Geological Society 43, 159-167.

Fairburn, R.A., 1999. Palaeocurent direction and velocity in the Great/Main Limestone on the Alston and Askrigg blocks of northern England. Proceedings Yorkshire Geological Society, 52, 353-359.

Fairburn, R.A., 2001. The stratigraphy of the Namurian Great/Main Limestone on the Alston Block, Stainmore Trough and Askrigg Block of northern England. Proceedings Yorkshire Geological Society 53, 265-274.

Gale, A.S., 1998. Cyclostratigraphy. In: Doyle, P., Bennett, M.R. (Eds). Unlocking the Stratigraphic Record. John Wiley, Chichester, pp. 195-220.

George, T.N., Johnston, G.A.L.J., Mitchell, M., Prentice, J.E., Ramsbottom, W.H.C., Sevastopulo, G.D., Wilson, R.B., 1976. A Correlation of the Dinantian Rocks in the British Isles. Special Report Geological Society of London, 7. 
Goldhammer, R.K., Oswald, E.J., Dunn, P.A., 1994. High-frequency glacio-eustatic cyclicity in the Middle Pennsylvanian of the Paradox Basin: an evaluation of Milankovitch forcing. In: de Boer, P.L. and Smith, DG. Orbital Forcing and Cyclic Sequences. International Association of Sedimentologists Special Publication 19, 243 293.

Gomez, F.J., Ogle, M., Astini, R.A., Kalini, R.M., 2007. Paleoenvironmental and carbon-oxygen isotope record of Middle Cambrian carbonates (La Laja Formation) in the Argentine Precordillera. Journal Sedimentary Research, 77, 826-842.

Gupta, A.K., Anderson, D.M., Overpeck, J.T., 2003. Abrupt changes in the Asian southwest monsoon during the Holocene and their links to the North Atlantic Ocean. Nature 421, 354-356.

Haigh, J.D., 1996. The impact of solar variability on climate. Science 272, 981-984.

Hardie, L.A., 1986. Stratigraphic models for carbonate tidal-flat deposition. Quarterly Journal Colorado School Mines 81, 59-74.

Heckel, P.H., 1986. Sea-level curve for Pennsylvanian eustatic marine transgressiveregressive depositional cycles along the mid-continent outcrop belt, North America. Geology 14, 330-334.

Hodge, B.L., Dunham, K.C., 1991. Clastics, coals, palaeodistributaries and mineralisation in the Namurian Great Limestone Cyclothem, Northern Pennines and Northumberland Trough. Proceedings Yorkshire Geological Society 48, 323-337.

Holliday, D.W., Burgess, I.C., Frost, D.V., 1975. A recorrelation of the Yoredale limestones (Upper Viséan) of the Alston Block with those of the Northumberland Trough. Proceedings Yorkshire Geological Society 45, 71-83.

Horbury, A.D., 1989. The relative roles of tectonics and eustasy in the deposition of the Urswick Limestone in south Cumbria and north Lancashire. Yorkshire Geological Society Occasional Publication 6, 153-169. 
Huls, M., Zahn, R., 2000. Millennial-scale sea-surface temperature variability in the western tropical North Atlantic from planktonic foraminiferal census counts. Paleoceanography 15, 659-678.

Johnson, G.A.L.J., 1958. Biostromes in the Namurian Great Limestone of northern England. Palaeontology 1, 147-157.

Johnson, G.A.L.J., 1984. Subsidence and sedimentation in the Northumberland Trough. Proceedings Yorkshire Geological Society 45, 71-83.

Leeder, M.R., Strudwick, A.E., 1987. Delta-marine interaction: a discussion of sedimentary models for Yoredale type cyclicity in the Dinantian of northern England. In: Miller, J., Adams, A.E., Wright, V.P. (Eds) European Dinantian Environments 115-130. John Wiley \& Sons, Chichester.

Lehrmann, D.J., Goldhammer, R.K., 1999. Secular variation in parasequence and facies stacking patterns of platform carbonates: a guide to application of stacking patterns analysis in strata of diverse facies and settings. In: Harris, P.M., Saller, A.H., Simo, J.A. (Eds). Advances in Carbonate Sequence Stratigraphy. Society of Economic Paleontologists and Mineralogists Special Publication 63, 187-225

Mawson, M., Tucker, M.E., 2008 Millennial-scale cycles in slope carbonates, Upper Permian (Zechstein) carbonates, NE England. Sedimentary Geology in review.

Maynard, J.R., Leeder, M.R., 1992. On the periodicity and magnitude of Late Carboniferous glacio-eustatic sea-level changes. Journal. Geological Society London $149,303-311$.

Moy, C.M., Seltzer, G.O., Rodbell, D.T., Anderson, D.M., 2002. Variability of El Nino/Southern Oscillation activity at millennial timescales during the Holocene epoch. Nature 420, 162-165. 
Mundil, R., Zuhlke, R., Bechstadt, T., Peterhansel, A., Sven O. Egenhoff, S.O., Oberli, F., Meier, M., Brack, P., Rieber, H , 2003. Cyclicities in Triassic platform carbonates: synchronizing radio-isotopic and orbital clocks. Terra Nova, 15, 81-87.

Noren, A.J., Bierman, P.R., Steig, E.J., Andrea Lini, A., Southon, J., 2002.

Millennial-scale storminess variability in the northeastern United States during the Holocene epoch. Nature 419, 821-824.

Potter, E.M., Esat, T.M., Schellmann, G., Radtke, U., Lambeck, K., McCulloch, M.T., 2004. Suborbital-period sea-level oscillations during marine isotope substages $5 \mathrm{a}$ and 5c. Earth \& Planetary Science Letters 225, 191-204.

Ramsbottom, W.H.C., 1973. Transgressions and regressions in the Dinantian: a new synthesis of the British Dinantian stratigraphy. Proceedings Yorkshire Geological Society 39, 567-607.

Rind, D., 1999. Latitudinal temperature gradients and climatic changes. Journal Geophysical Research 103, 5943-5971.

Ross, C.A., Ross, J.R.P., 1987. Late Paleozoic transgressive-regressive deposition. In Wilgus, C.K., Hastings, B.S., Kendall, C.G.St.C., Posamentier, H.W., Ross, C.A., Van Wagoner, J.C. (Eds). Sea-Level Changes: an Integrated Approach. Society of Economic Paleontologists \& Mineralogists Special Publication 42, 227-248.

Roth, S., Reijmer, J.J.G., 2005. Holocene millennial to centennial carbonate cyclicity recorded in slope sediments of the Great Bahama Bank and its climatic implications. Sedimentology 52, 161-181.

Sarntheim, M., Kennett, J.P., Allen, J.R.M., Beer, J., Grootes, P., Laj, C., McManus, J., Ramesh, R., SCOR-IMAGES Working Group 117, 2002. Decadal-to-millennial scale climate variability - chronology and mechanisms: summary and recommendations. Quaternary Science Reviews 21, 1121-1128. 
Simpson, J., 1985. Stylolite-controlled layering in a homogeneous limestone: pseudobedding produced by burial diagenesis. Sedimentology 32, 495-505.

Schlager, W., 2003. Benthic carbonate factories of the Phanerozoic. International Journal of Earth Sciences 92, 1-26.

Schlager, W., 2005. Carbonate Sedimentology and Sequence Stratigraphy. SEPM Studies in Geology, 8, pp. 200.

Schwarzacher, W., 1993. Cyclostratigraphy and the Milankovitch Theory. Elsevier, Amsterdam, pp. 225.

Smith, L.B., Read, J.F., 2000. Rapid onset of late Palaeozoic glaciation on Gondwana: evidence from Upper Mississippian strata of the Mid-continent, U.S.A. Geology 28, 279-282.

Smith, L.B., Read, J.F., 2001. Discrimination of local and global effects on Upper Mississippian stratigraphy, Illinois Basin, U.S.A. Journal of Sedimentary Research 71, 985-1002.

Thompson, W.G., Goldstein, S.L., 2005. Open-system coral ages reveal persistent suborbital sea-level cycles. Science 308, 401-404.

Tucker, M.E., 1993. Carbonate diagenesis and sequence stratigraphy. In: V.P.Wright (Ed.) Sedimentology Review 1, 51-72. Blackwell Science, Oxford.

Tucker, M.E., 2003a. Mixed clastic-carbonate cycles and sequences: Quaternary of Egypt and Carboniferous of England. Geologica Croatica 56, 19-37.

Tucker, M.E., 2003b. Sedimentary Rocks in the Field. John Wiley, Chichester, $3^{\text {rd }}$ Edition, pp. 234. 
Tucker, M.E., Gallagher, J., Lemon, K., Leng, M., 2003. The Yoredale cycles of Northumbria: high frequency clastic-carbonate sequences of the Mid-Carboniferous icehouse world. Open University Geological Society Journal 24, 5-10.

Tucker, M.E., Wright, V.P., 1990. Carbonate Sedimentology. Blackwell Science, Oxford. pp. 482.

Van Geel, B., Raspopov, O.M., Renssen, H., van der Plicht, J., Dergachev, V.A., Meijer, H.A.J., 1999. The role of solar forcing upon climate change. Quaternary Science Reviews 18, 331-338.

Veevers, J.J., Powell, M., 1987. Late Paleozoic glacial episodes in Gondwanaland reflected in transgressive-regressive depositional sequences in Euramerica. Geological Society of America Bulletin 98, 475-487.

Walkden, G.M., 1987. Sedimentary and diagenetic styles in mid-Dinantian carbonates of Britain. In: Miller, J., Adams, A.E., Wright, V.P. (Eds) European Dinantian Environments 131-155. John Wiley \& Sons, Chichester.

Wright, V.P., 1994. Early Carboniferous carbonate systems: an alternative to the Cainozoic paradigm. Sedimentary Geology 93, 1-5

Wright, V.P., 1986. Facies sequences on a carbonate ramp: the Carboniferous Limestone of South Wales. Sedimentology 33, 221-241.

Wright, V.P., Cherns, L., 2004. Are there 'black holes' in carbonate deposystems? Geologica Acta 2, 285-290.

Wright, V.P., Vanstone, S.D., 2001. Onset of late Palaeozoic glacio-eustasy and the evolving climates of low latitudes: a synthesis of current understanding. Journal Geological Society London 158, 579-582. 
Yancheva, G., Nowaczyk, N.R., Mingram, J., Dulski, P., Schettler, G., Negendank, Jorg, F.W., Liu, J., Sigman, D.M., Peterson, L.C., Haug, G.H., 2007. Influence of the intertropical convergence zone on the East Asian Monsoon. Nature 445, 74-77.

Zühlke, R., Bechstadt, T., Mundil, R., 2003. Sub-Milankovitch and Milankovitch forcing on a model Mesozoic carbonate platform - the Latemar (Middle Triassic, Italy). Terra Nova 15, 69-80. 


\section{Captions to Figures}

Fig. 1 Location map for northern England showing the blocks and basins, which, except for the Central Pennine Basin, were zones of only differential subsidence during the Carboniferous with uniform facies across the region. The Central Pennine Basin was a real deepwater basin.

Fig. 2 Schematic graphic logs for 2 types of Yoredale cycle with sequence stratigraphic interpretations: a) with deltaic clastic facies in the upper part and several minor cycles at the top, and b) with an incised-valley fill in the upper part.

Fig. 3 Sedimentological and sequence stratigraphic model for deposition of a typical Yoredale cycle.

Fig. 4 The Great Limestone Cyclothem (Pendleian, basal Namurian) showing 20metre thick Great Limestone in the lower part, with well-developed bedding, overlain by prodelta mudrocks which are cut into by a coarse sandstone body that represents an incised-valley fill. Frosterley, Weardale, Pennines. Height of Cliff 30 metres.

Fig. 5. Sequence stratigraphic model for the Yoredale cycles based on orbital forcing and climate-forcing processes.

Fig. 6 Photomicrograph of a typical Great Limestone sample showing abundance of bioclastic debris, including brachiopod, crinoid and replaced aragonitic skeletal material in a dark micritic matrix. Scale bar $2 \mathrm{~mm}$.

Fig. 7 Photomicrograph of a typical Great Limestone sample showing several foraminifera, shells and other bioclastic debris in a micritic-microsparitic matrix. Scale bar $1 \mathrm{~mm}$.

Fig. 8 Corals, brachiopods and other bioclastic debris in the Great Limestone. Field of view $6 \times 12 \mathrm{~cm}$.

Fig. 9 The coral Dibunophyllum forms the Frosterley 'marble', a 20-cm thick coral 'biostrome' traceable over many $100 \mathrm{~s}$ of $\mathrm{km}^{2}$ and much sought after as an ornamental stone in medieval times. Field of view $30 \times 50 \mathrm{~cm}$.

Fig. 10 Productid brachiopods in growth position in the Great Limestone. Field of view 10 × $20 \mathrm{~cm}$.

Fig. 11 Yoredale limestone with beds $20-60 \mathrm{~cm}$ thick defined by mm-thick shale partings and $\mathrm{cm}$-thick mudstone layers. Height of cliff 2.5 metres.

Fig. 12 Log of the Great Limestone itself from Middleton-in-Teesdale and the oxygen isotope pattern. Shown here are the bed numbers (1-25), bed thicknesses, the names of the individual beds used by the quarrymen and miners, the occurrence of stylolites and pressure dissolution planes, and the location of the fossil bands ('biostromes'), notably the Frosterley 'marble' in the Crabby beds. 
Fig. 13. Bed-thickness pattern for the Great Limestone at Bollihope, Weardale. A. Data displayed as a Fischer plot: thickness of each bed (vertical line) successively through the limestone compared with the average thickness (diagonal line). B. Data displayed as a histogram.

Fig. 14 Bed-thickness patterns for the Great Limestone at 11 localities in Weardale and Teesdale in the Pennine Hills displayed as cumulative deviations of bed thickness from the average (a 'Fischer' plot) through the succession.

Fig. 15 A. Oxygen isotope data plotted stratigraphically through the Great Limestone with the 12-point moving average. B. Generalised trend of the oxygen isotope data plotted as deviation from the average to emphasize the stratigraphic pattern. C. Deviation of bed thickness from average bed thickness for Middleton-in-Teesdale, the locality of the geochemical sampling.

Fig. 16 Oxygen isotope patterns across several beds within the Great Limestone, showing more negative values towards bed margins and less negative values within bed centres.

Fig. 17 Plot of strontium trace element data ( $\mathrm{ppm})$ through the Great Limestone, along with the 12-point moving average. Also shown (upper dashed curve) is the bed thickness variation.

Fig. 18 Sketch graphic log of the Great Limestone Cyclothem near Stanhope, Weardale, showing the half-clastic, half-carbonate nature of the cyclothem, the 4 minor cycles in the clastics and the major channel fill which cuts down through 2 minor cycles.

Fig. 19 Possible explanations for the origin of the bed-sets in the Great Limestone, together with the generalised pattern of trends in the $\delta^{18} \mathrm{O}$ data. Zones of thicker beds in the bed-sets could be the result of higher carbonate productivity due to shallower water, clearer seas/lower rainfall (more arid climate) or higher temperature. Zones of thinner beds in bed-sets could be the result of lower carbonate productivity due to deeper water or more turbid seas/higher rainfall (more humid climate) or lower temperature. The pattern of the $\delta^{18} \mathrm{O}$ data suggests that temperature itself is not the control, but does lend support to a depth/sea-level/ice-cap size control and/or a salinity-turbidity (arid-humid climate) explanation.

Fig. 20 Possible explanations for the origin of the beds in the Great Limestone. The limestone beds, as opposed to the partings/mudstone interbeds which define the beds, could be the result of higher carbonate productivity in shallower water, with the clay input through a sea-level rise (reworking of mudflats), OR warmer water promoting limestone deposition and cooler water reducing carbonate productivity allowing clay to be deposited, OR a more arid climate (clearer seas) during limestone deposition, then a change to a more humid climate (increased fluvial input) for the influx of the clay. The pattern of the $\delta^{18} \mathrm{O}$ data suggests that temperature itself is not the control, but does support a depth/sea-level and/or salinity (arid-humid climate) explanation.

Fig. 21 A parasequence in the Soldano Member, Upper Cambrian, Precordillera, Argentina, showing a clear pattern of bed thickness increasing up towards the top of 
the parasequence, with beds defined by shale partings. Photo courtesy of Fernando Gomez.

Table 1 Lithostratigraphy of Carboniferous strata of northern England for the Northumberland Basin, with near-continuous deposition from the Devonian, and for the Alston Block, which was subaerially exposed until early Asbian times.

Table 2 Oxygen isotope data for the Great Limestone, samples taken at $\sim 15 \mathrm{~cm}$ intervals through the succession. Samples analysed in standard procedure for calcite at the NERC Isotope Geosciences Laboratory, British Geological Survey, Keyworth, Nottingham.

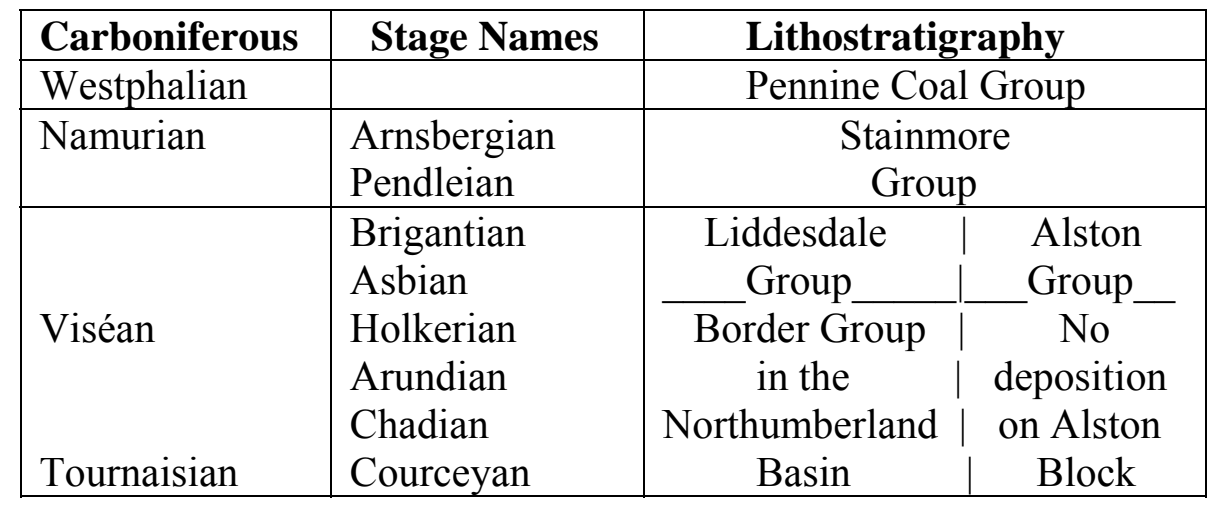

Table 1 Lithostratigraphy of Carboniferous strata of northern England for the Northumberland Basin, with near-continuous deposition from the Devonian, and Alston Block where the area was subaerially exposed until early Asbian times. 
Table 2 Oxygen isotope data for the Great Limestone, samples taken at $\sim 15 \mathrm{~cm}$ intervals through the succession. Samples analysed in standard procedure for calcite at the NERC Isotope Geosciences Laboratory, British Geological Survey, Keyworth, Nottingham.

$\begin{array}{cccccccccc}\text { sample } & \delta 180 & \text { sample } & \delta 180 & \text { sample } & \delta 180 & \text { sample } & \delta 180 & \text { sample } & \delta 180 \\ 1 & -10.2 & 34 & -11.5 & 64 & -11.4 & 94 & -10.4 & 127 & -12.7 \\ 2 & -9.7 & 35 & -9.4 & 65 & -11.1 & 95 & -7.8 & 128 & -8.1 \\ 3 & -9.3 & 36 & -10.7 & 66 & -9.1 & 96 & -10.5 & 129 & -9.1 \\ 4 & -8.5 & 37 & -10.2 & 67 & -9.4 & 97 & -10.0 & 130 & -9.4 \\ 5 & -9.8 & 38 & -10.6 & 68 & -8.3 & 98 & -10.5 & 131 & -11.0 \\ 6 & -9.1 & 39 & -10.5 & 69 & -9.2 & 99 & -12.1 & 132 & -9.0 \\ 7 & -10.1 & 40 & -8.7 & 70 & -10.5 & 100 & -10.4 & 133 & -9.5 \\ 8 & -9.4 & 41 & -9.5 & 71 & -9.1 & 101 & -12.5 & 134 & -11.1 \\ 9 & -7.8 & 42 & -9.1 & 72 & -9.2 & 102 & -10.5 & 136 & -12.5 \\ 10 & -8.3 & 43 & -11.6 & 73 & -10.3 & 103 & -11.6 & 137 & -9.6 \\ 11 & -8.5 & 44 & -12.2 & 74 & -11.0 & 104 & -11.5 & 138 & -9.0 \\ 12 & -8.1 & 45 & -11.9 & 75 & -9.8 & 105 & -12.0 & 139 & -12.0 \\ 13 & -8.9 & 46 & -10.8 & 76 & -10.2 & 106 & -11.9 & 140 & -9.0 \\ 15 & -10.9 & 47 & -10.2 & 77 & -10.6 & 107 & -11.1 & 141 & -9.7 \\ 16 & -11.4 & 48 & -10.3 & 78 & -10.7 & 108 & -11.1 & 142 & -12.3 \\ 17 & -11.0 & 49 & -10.5 & 79 & -10.6 & 109 & -11.8 & 143 & -11.9 \\ 18 & -9.1 & 50 & -12.2 & 80 & -10.9 & 110 & -11.8 & 144 & -10.4 \\ 19 & -10.3 & 51 & -11.2 & 81 & -11.0 & 113 & -8.0 & 145 & -10.9 \\ 20 & -11.8 & 52 & -10.2 & 82 & -10.3 & 114 & -7.9 & 146 & -10.1 \\ 22 & -12.2 & 53 & -9.1 & 83 & -11.4 & 115 & -10.4 & 147 & -10.9 \\ 23 & -9.0 & 54 & -11.1 & 84 & -9.9 & 116 & -13.1 & 148 & -8.3 \\ 24 & -9.4 & 55 & -12.3 & 85 & -10.4 & 117 & -8.1 & 149 & -13.6 \\ 25 & -10.2 & 56 & -9.9 & 86 & -10.4 & 118 & -9.9 & & \\ 26 & -9.3 & 57 & -10.5 & 87 & -12.2 & 120 & -11.6 & & \\ 27 & -12.5 & 58 & -12.2 & 88 & -10.0 & 121 & -8.9 & & \\ 28 & -12.0 & 59 & -12.2 & 89 & -10.0 & 122 & -8.6 & & \\ 30 & -11.8 & 60 & -8.8 & 90 & -11.6 & 123 & -10.3 & & \\ 31 & -12.4 & 61 & -10.0 & 91 & -11.2 & 124 & -9.6 & & \\ 32 & -12.8 & 62 & -9.9 & 92 & -8.7 & 125 & -8.2 & & \\ 33 & -10.1 & 63 & -12.2 & 93 & -12.3 & 126 & -12.1 & & \end{array}$




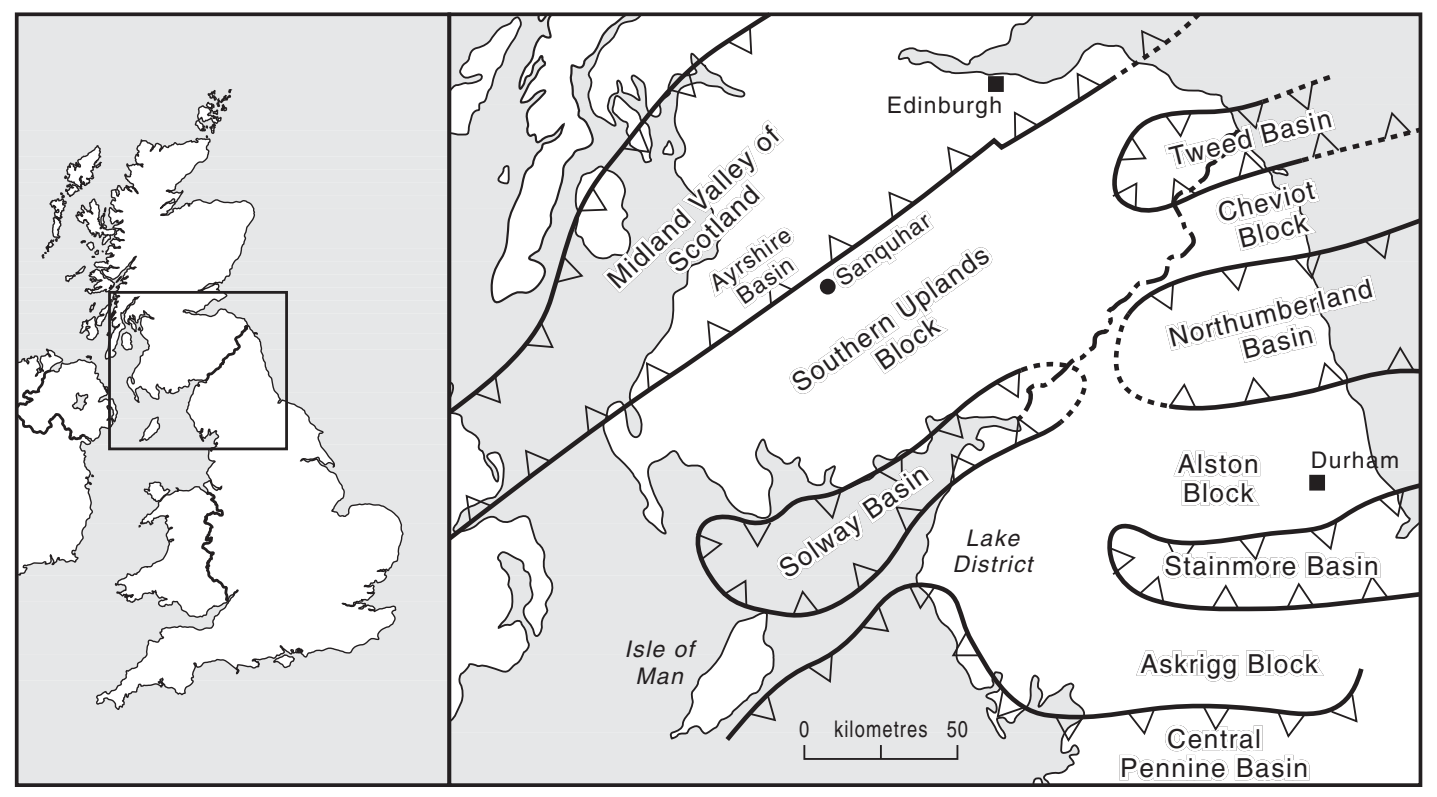

Figure 1 

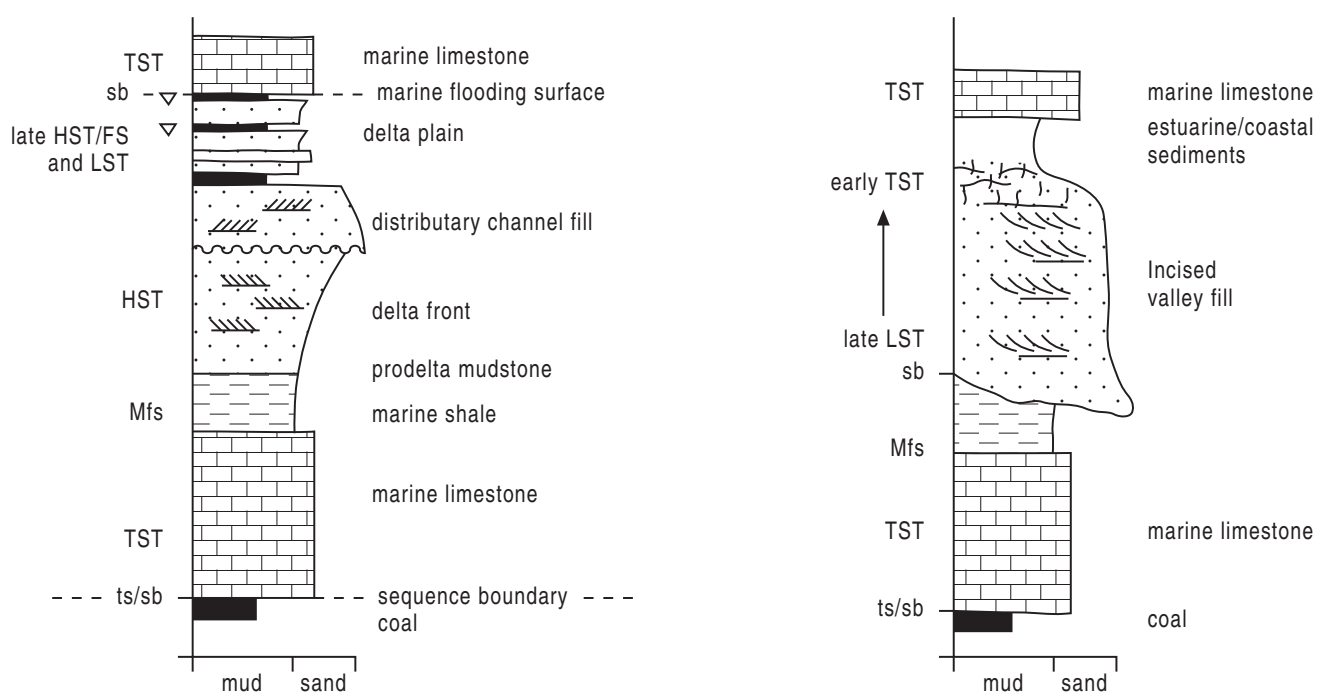

Figure 2 


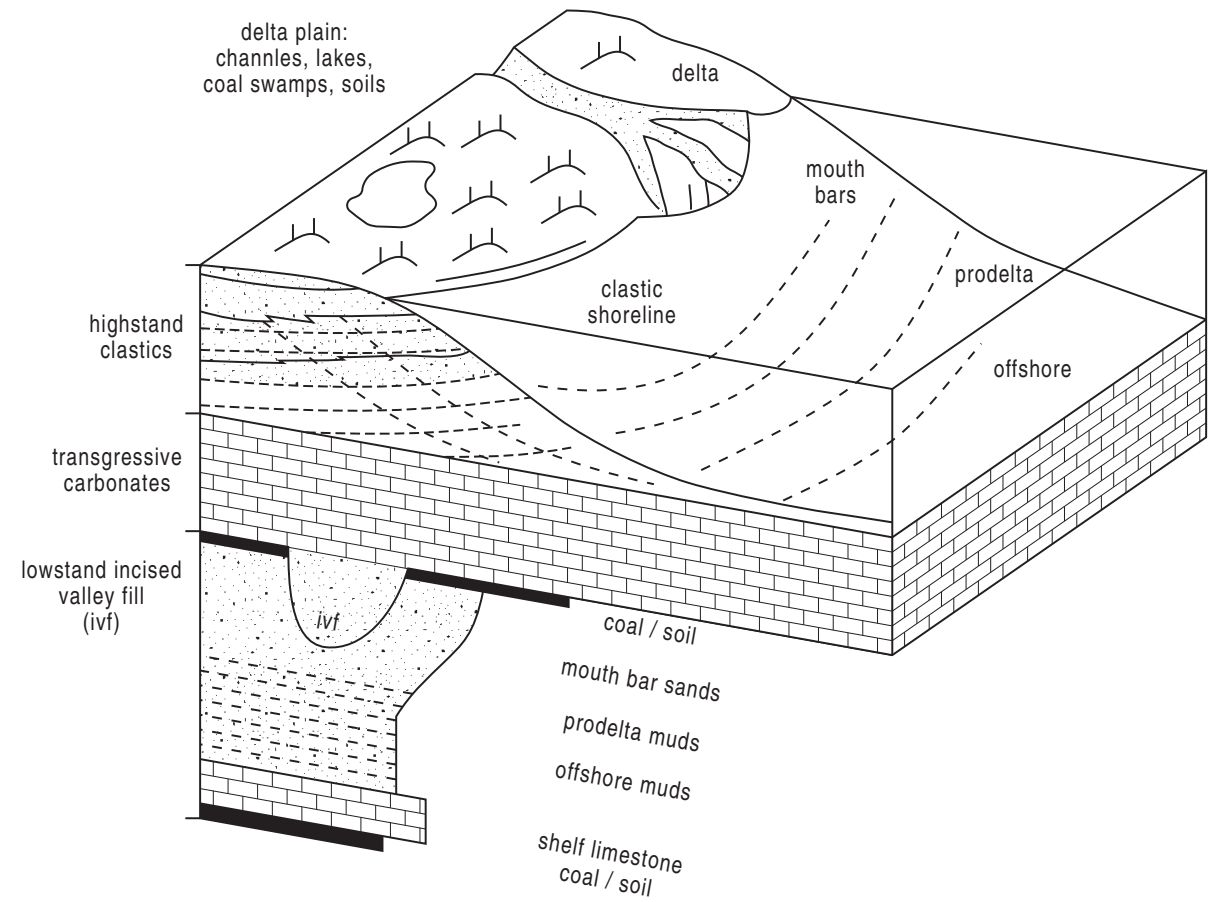

Figure 3 


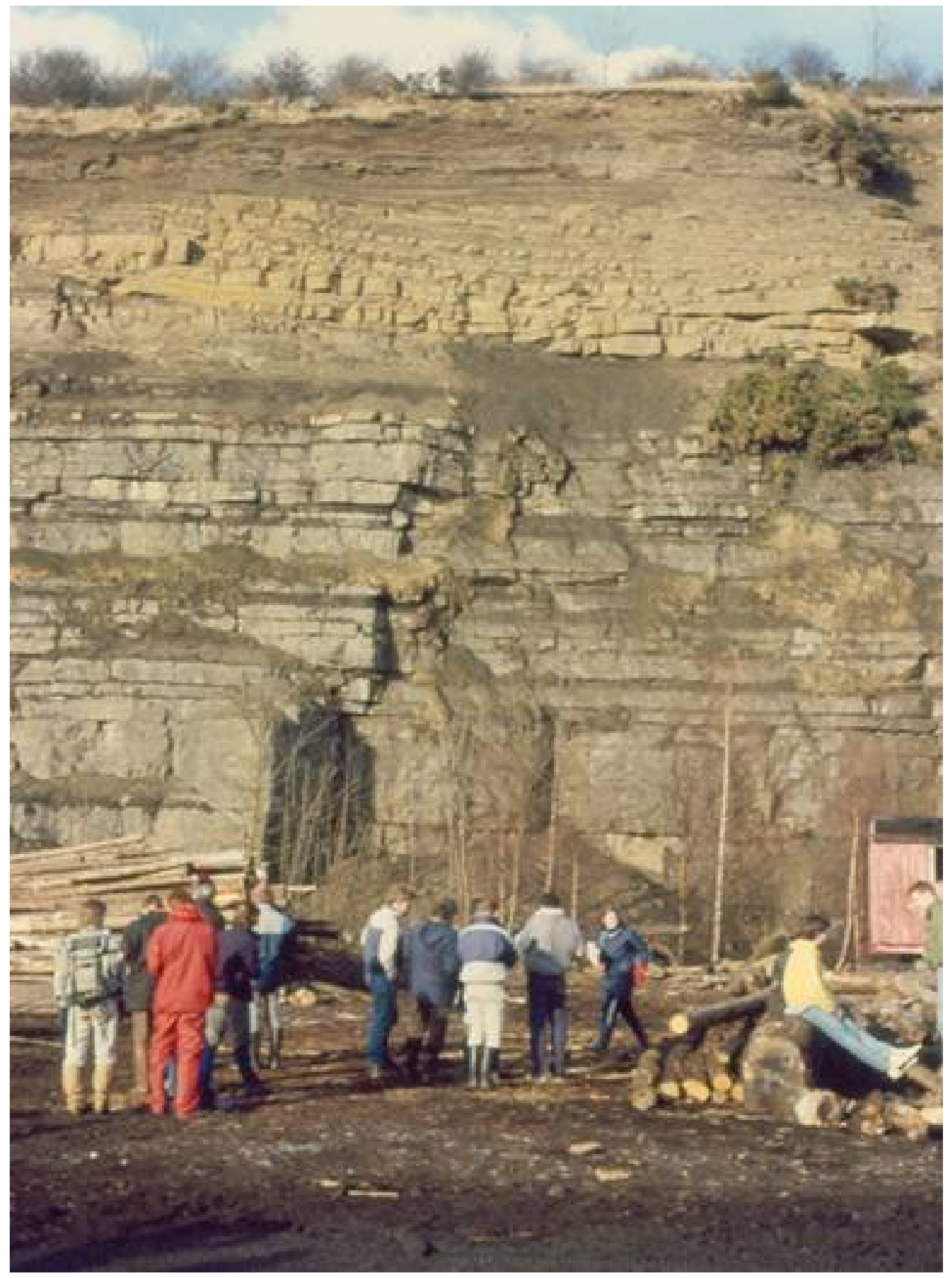

Figure 4 


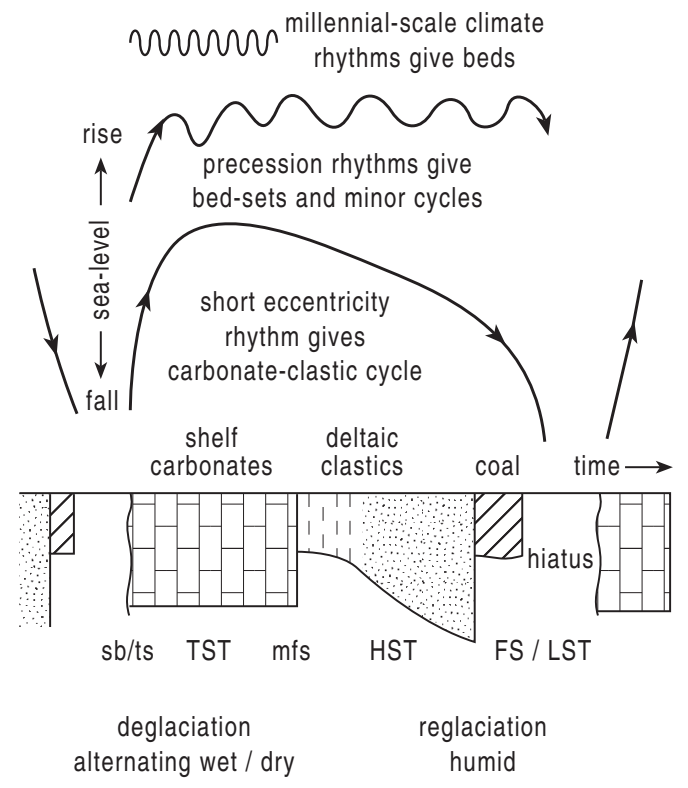

Figure 5 


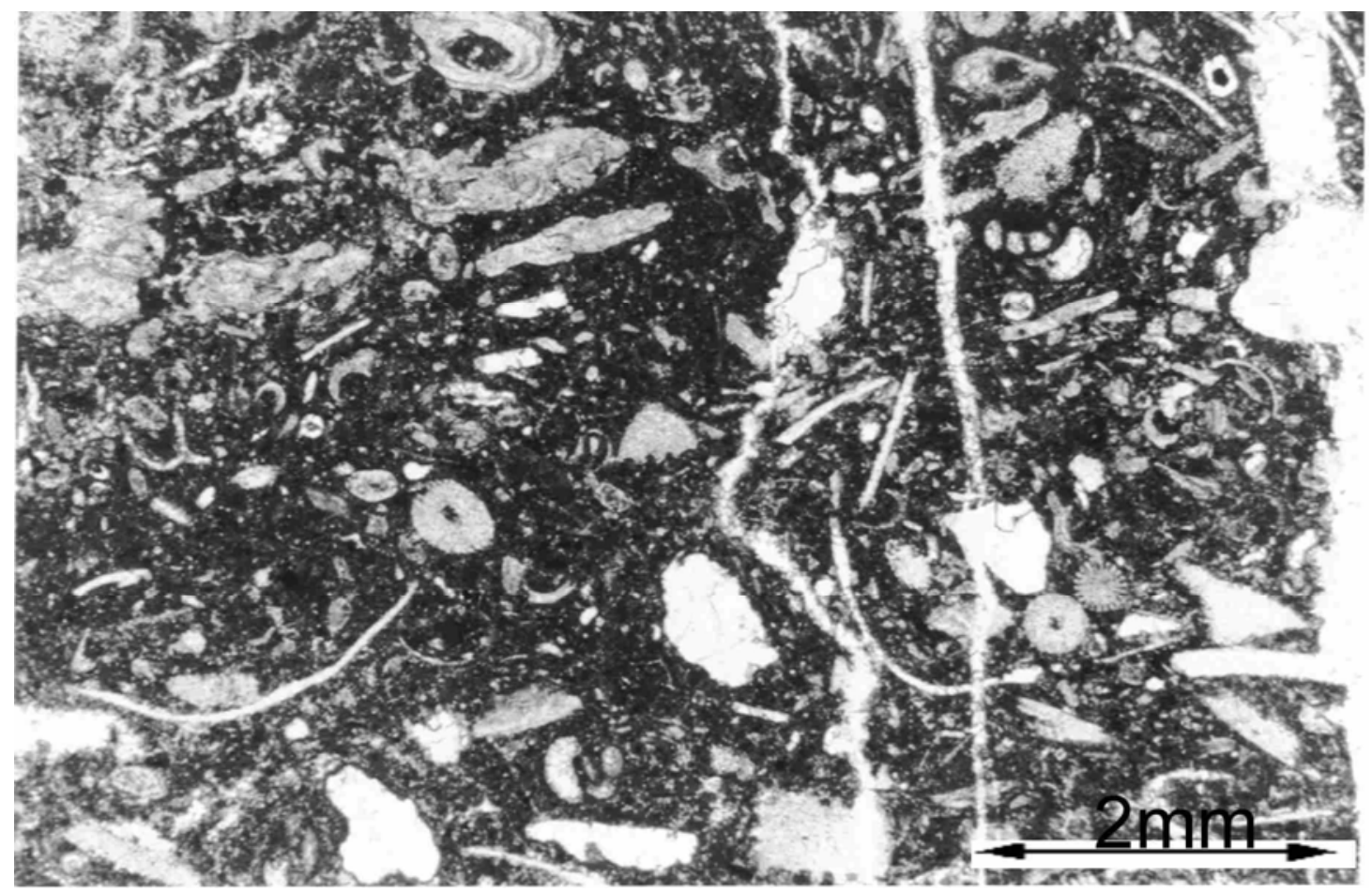

Figure 6 


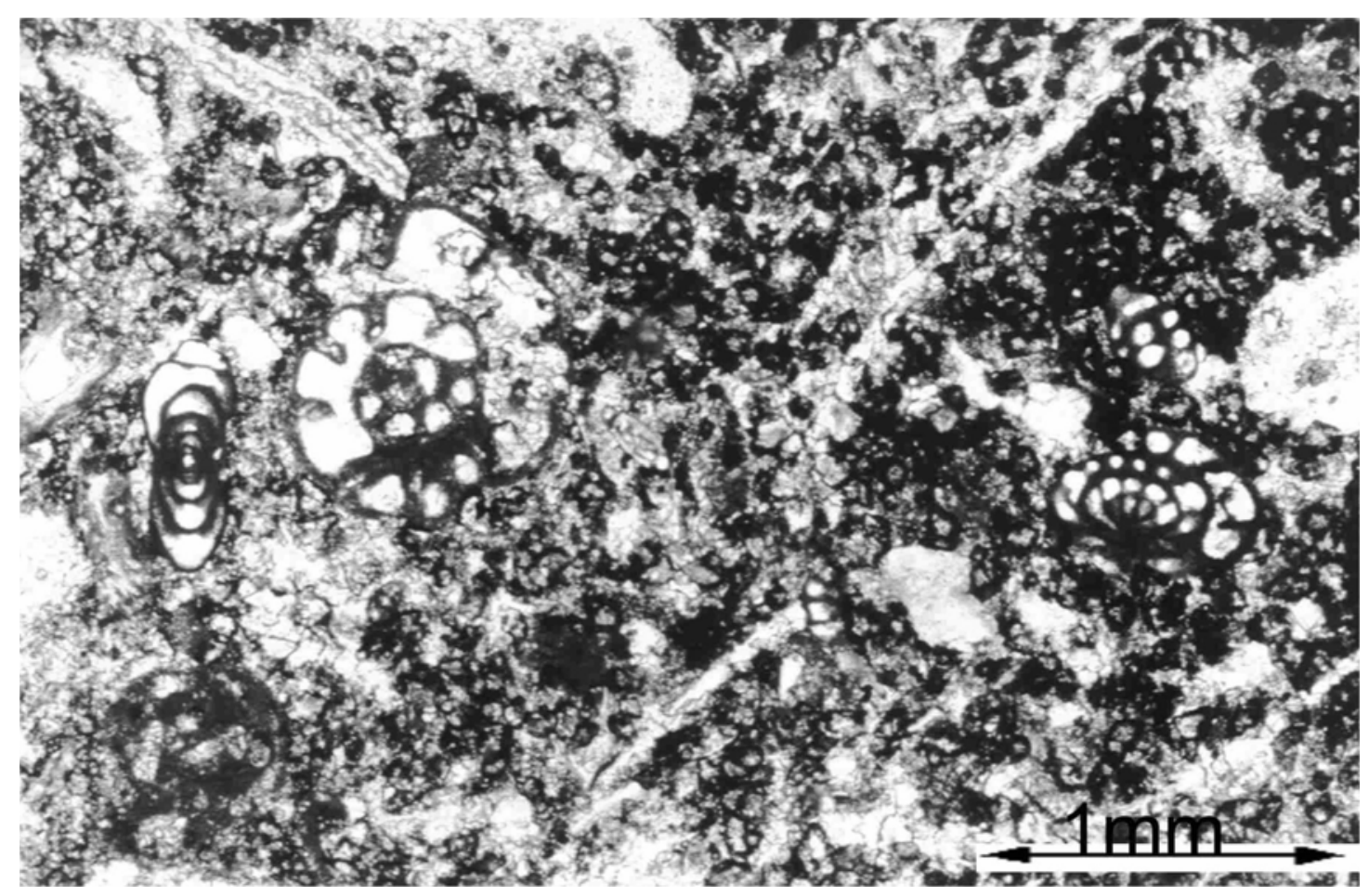

Figure 7 


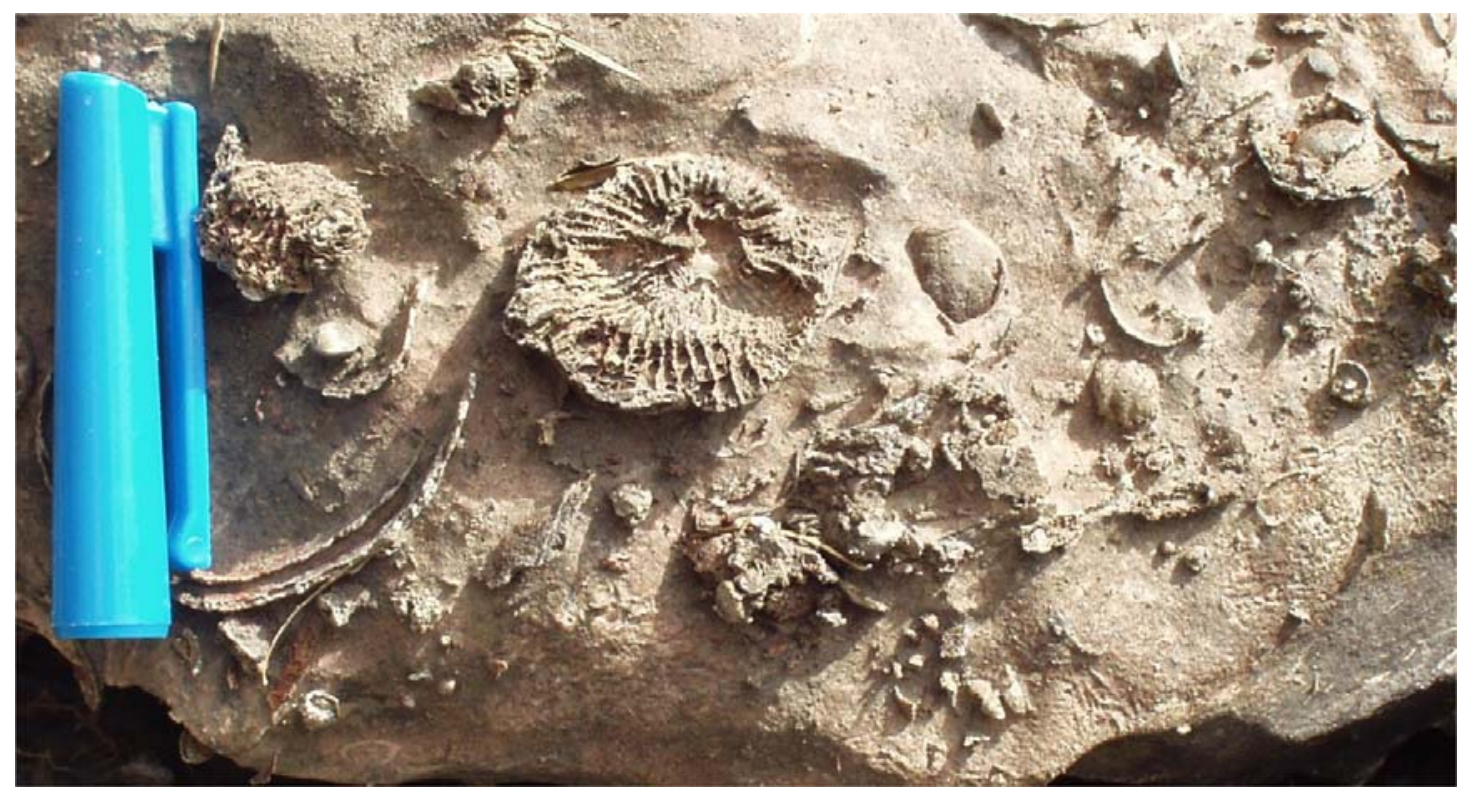

Figure 8 


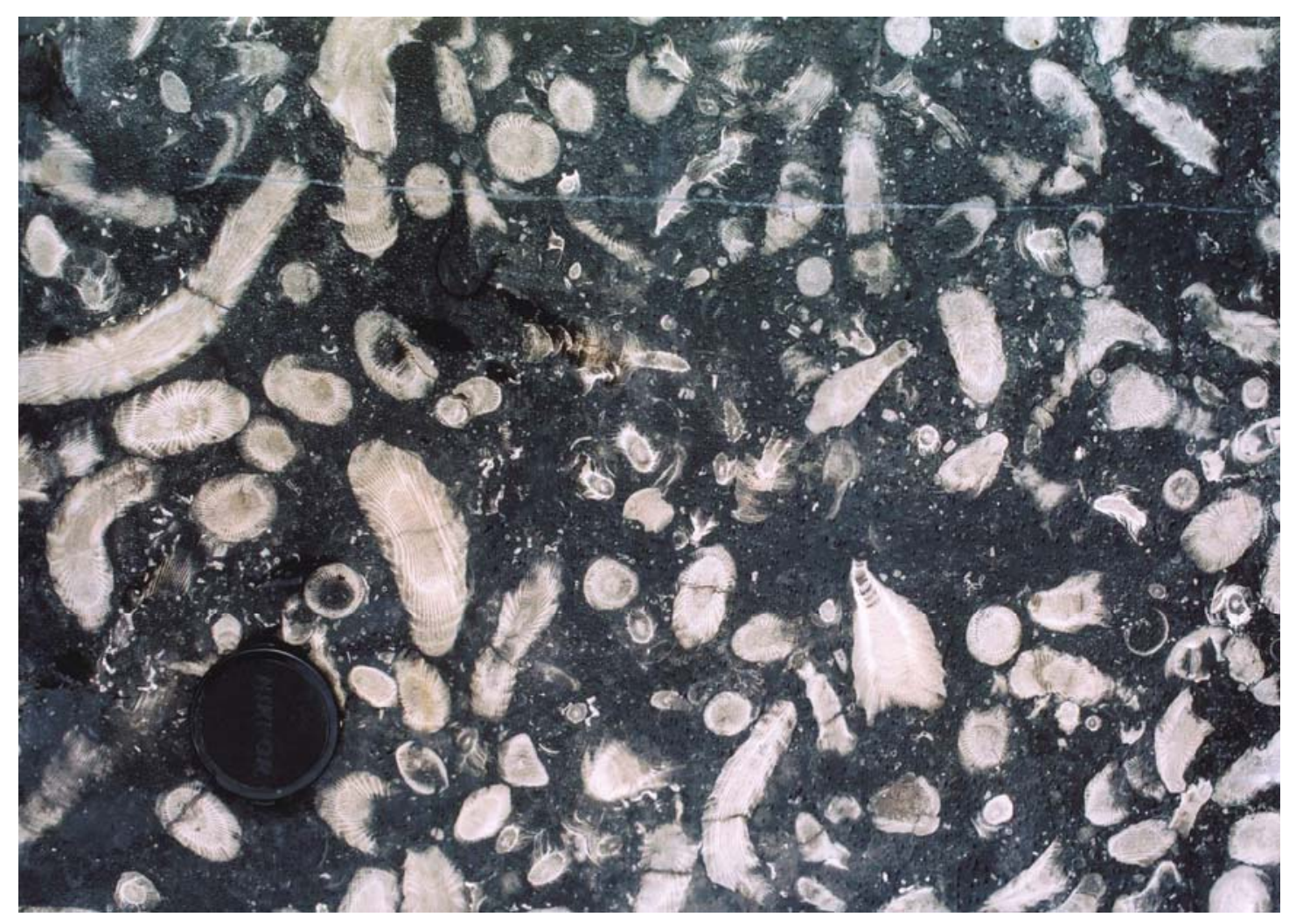

Figure 9 


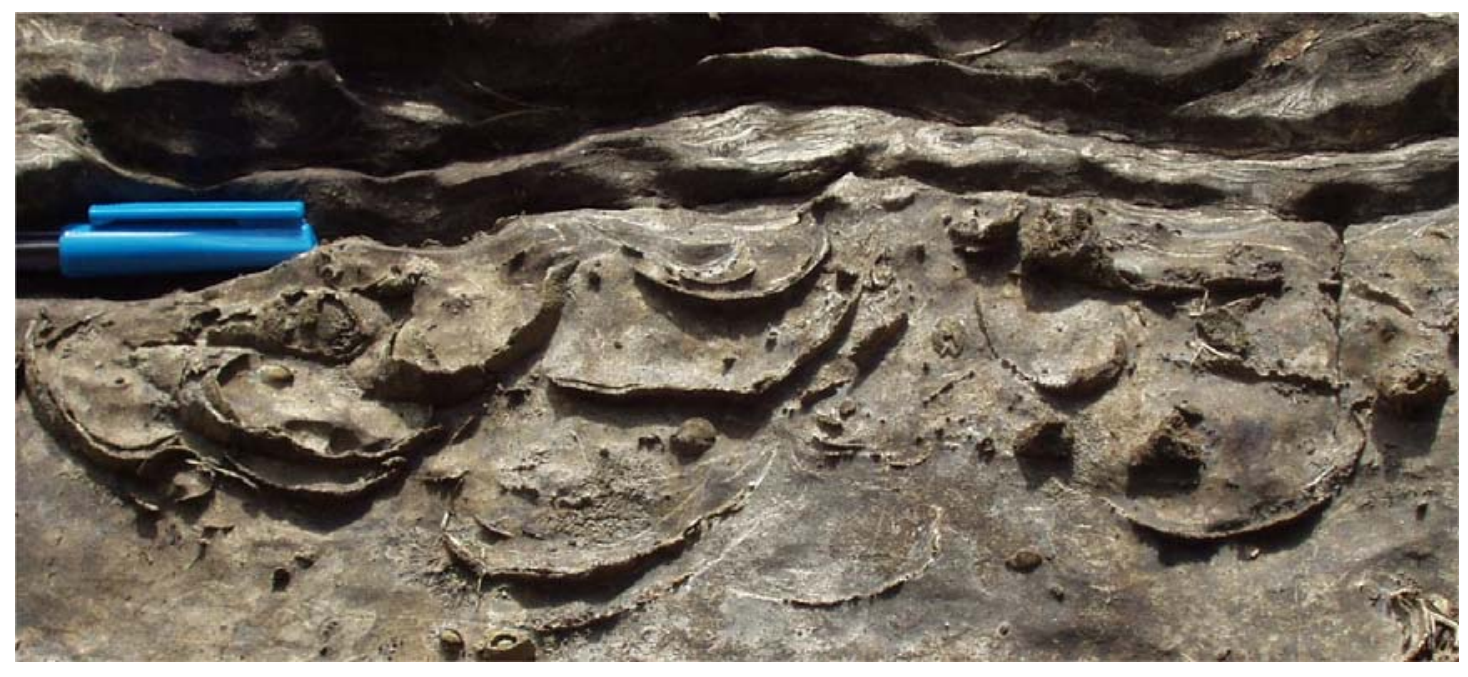

Figure 10 


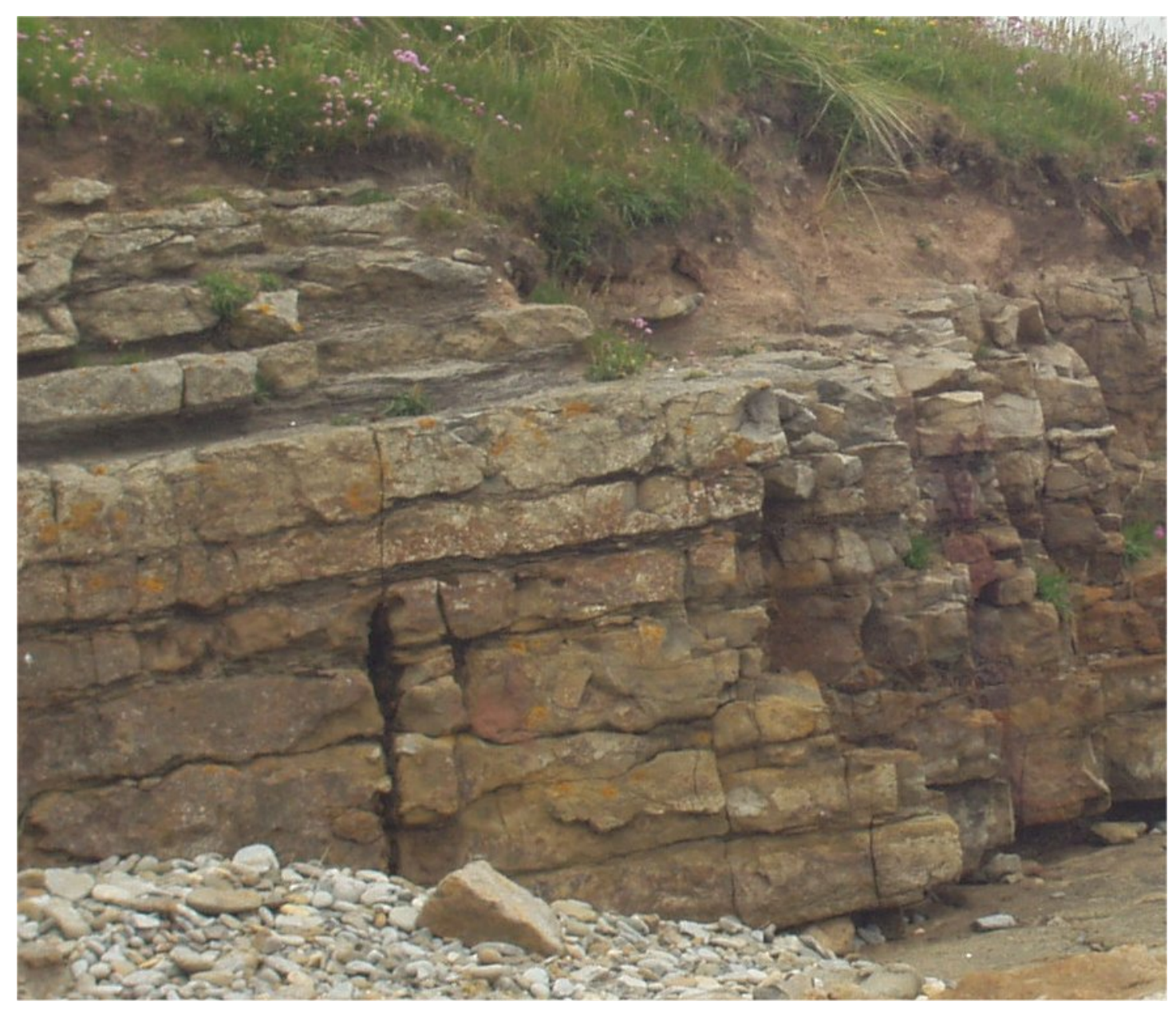

Figure 11 
Middleton In Teesdale, Hudeshope Beck

Grid Refs (Jacks Scar) 394784527610 and (Skears Quarry) 394916527276

\begin{tabular}{|c|c|c|c|c|}
\hline Local bed names & Bed no. & $\begin{array}{l}\text { Bed } \\
\text { thickness }\end{array}$ & $\begin{array}{c}\text { Major stylolite \& } \\
\text { muddy parting } \\
\text { positions }\end{array}$ & $\begin{array}{c}\text { Major biostrome } \\
\text { (coral \& brachiopod) } \\
\text { positions }\end{array}$ \\
\hline
\end{tabular}

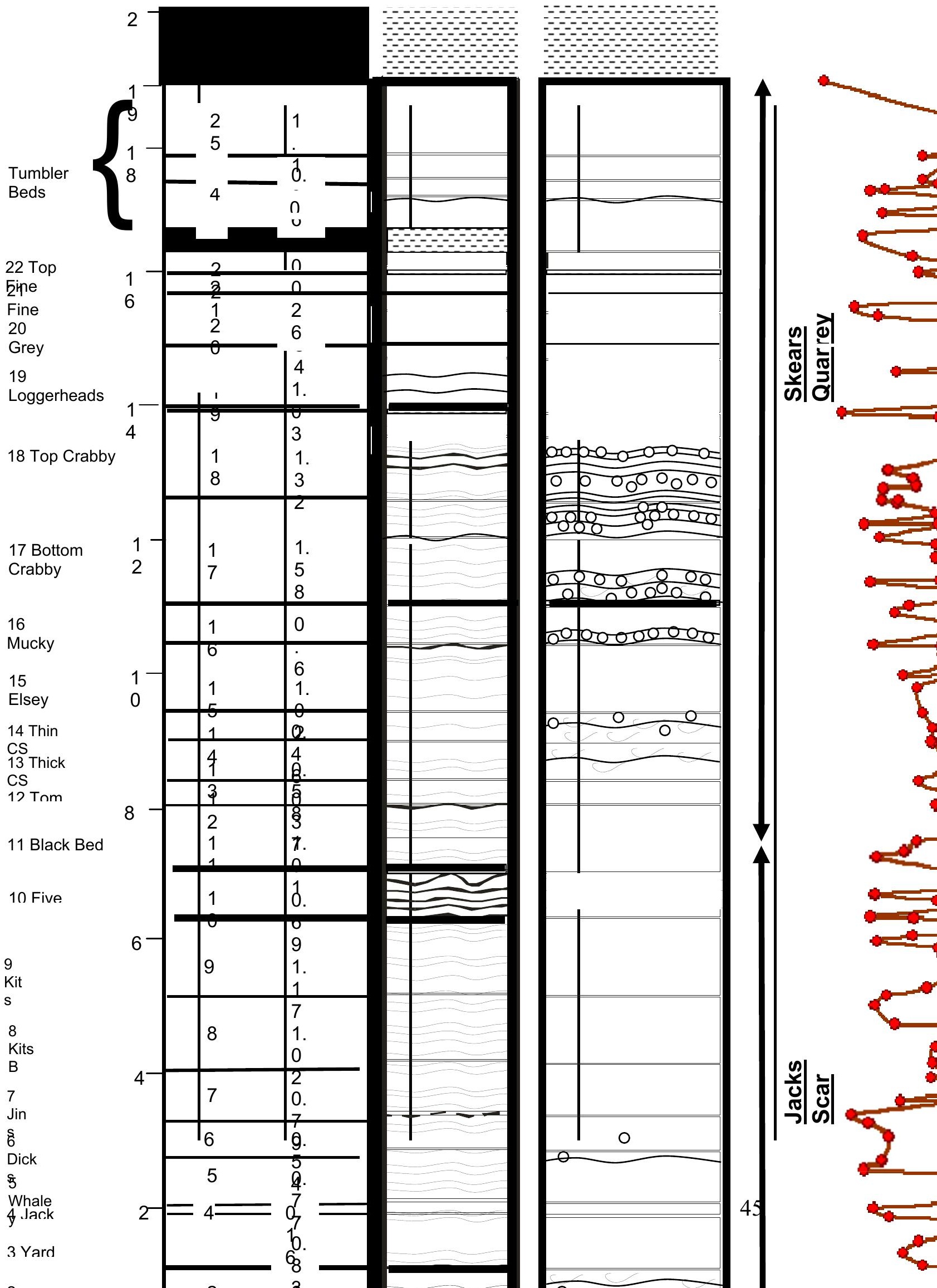




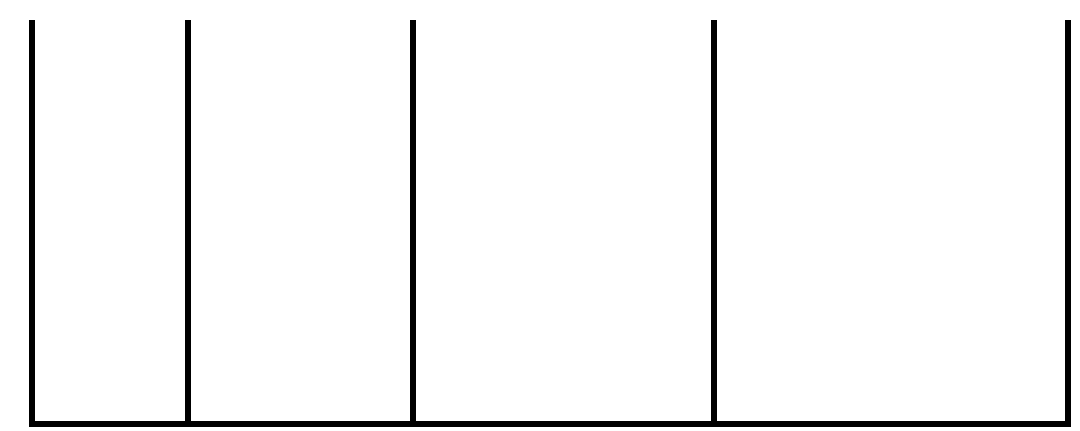

Figure 12 (an Excel file) has not copied and pasted well!! 

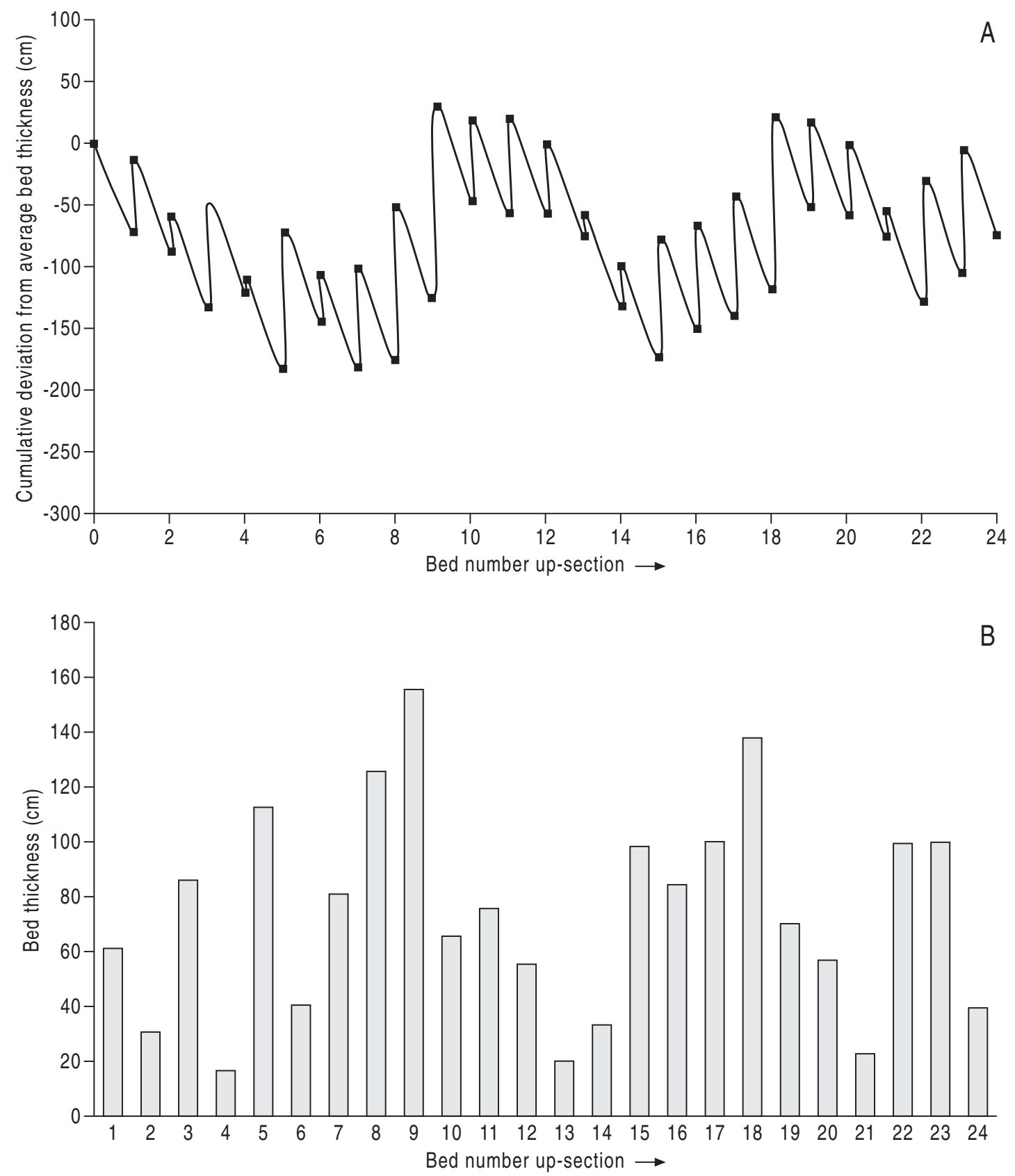

Figure 13 


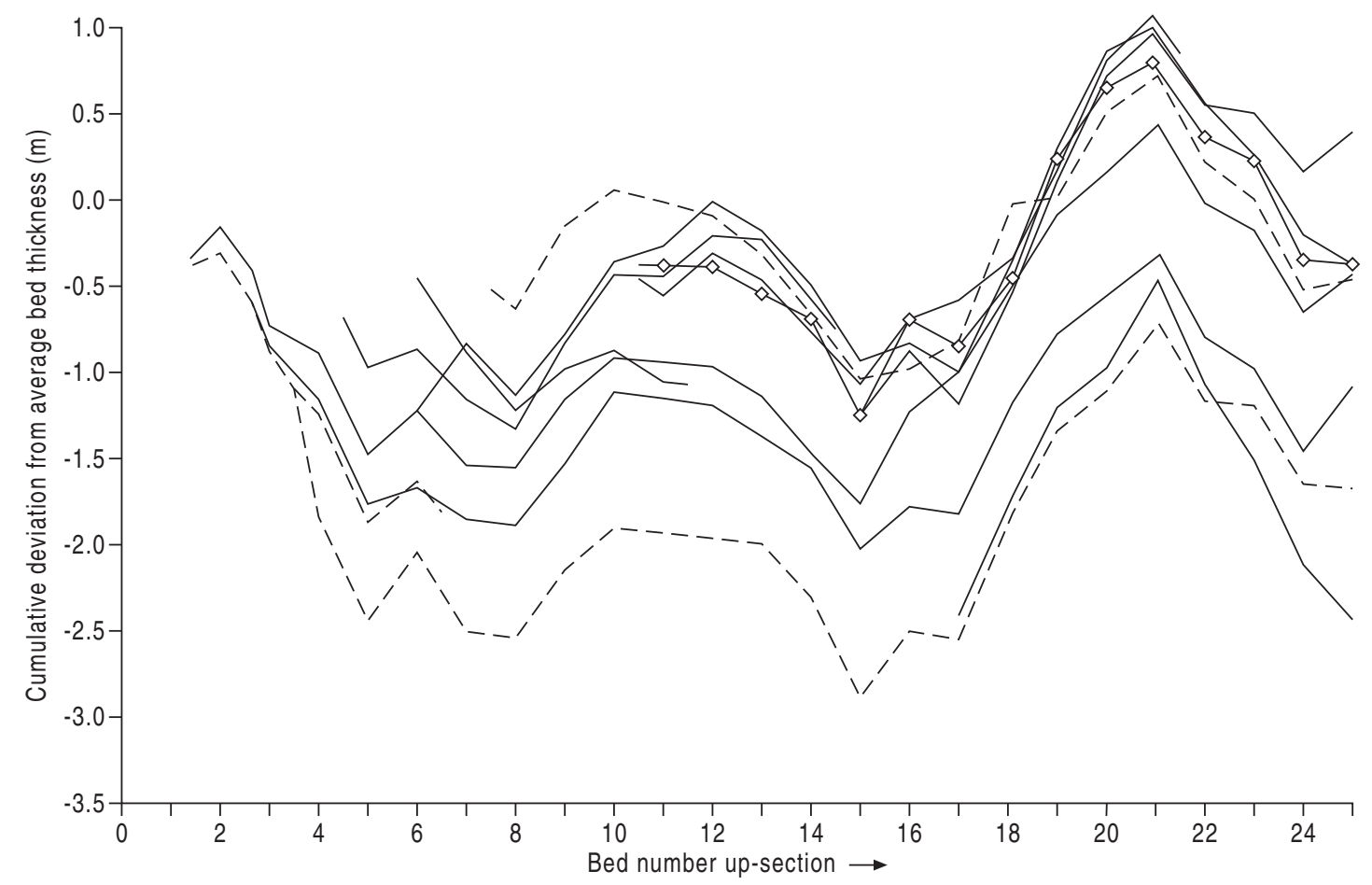

Figure 14 

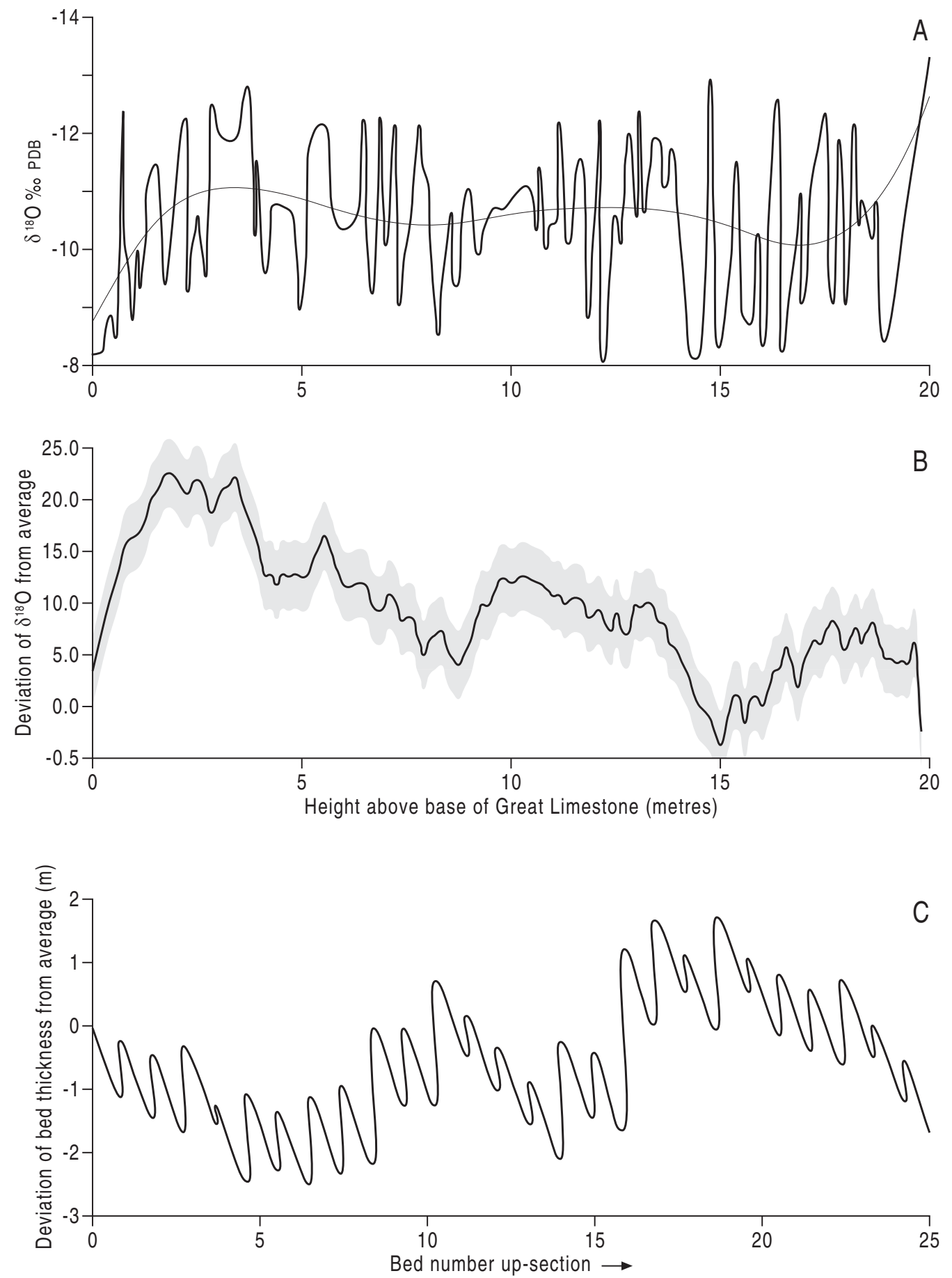

Figure 15 

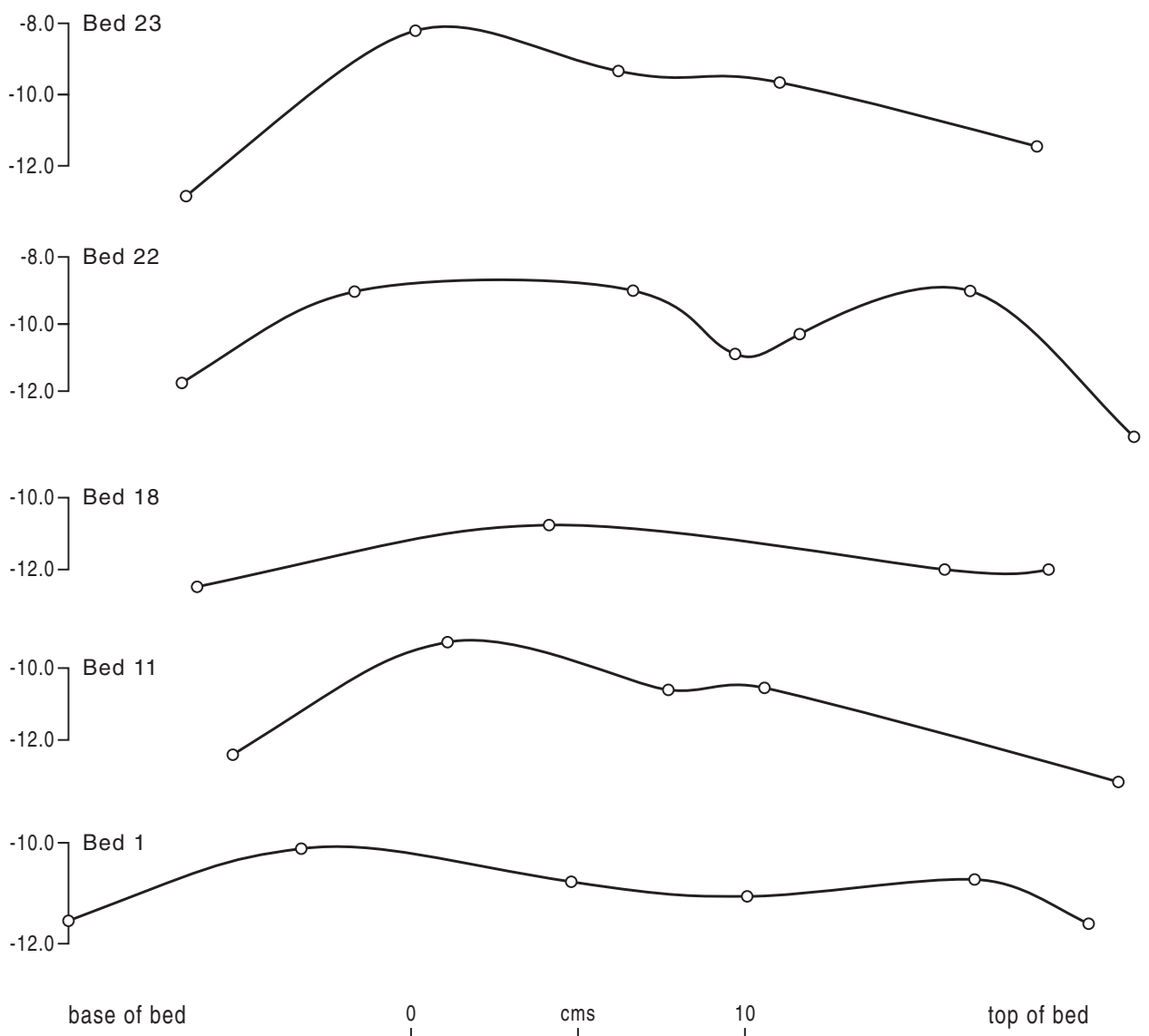

Figure 16 


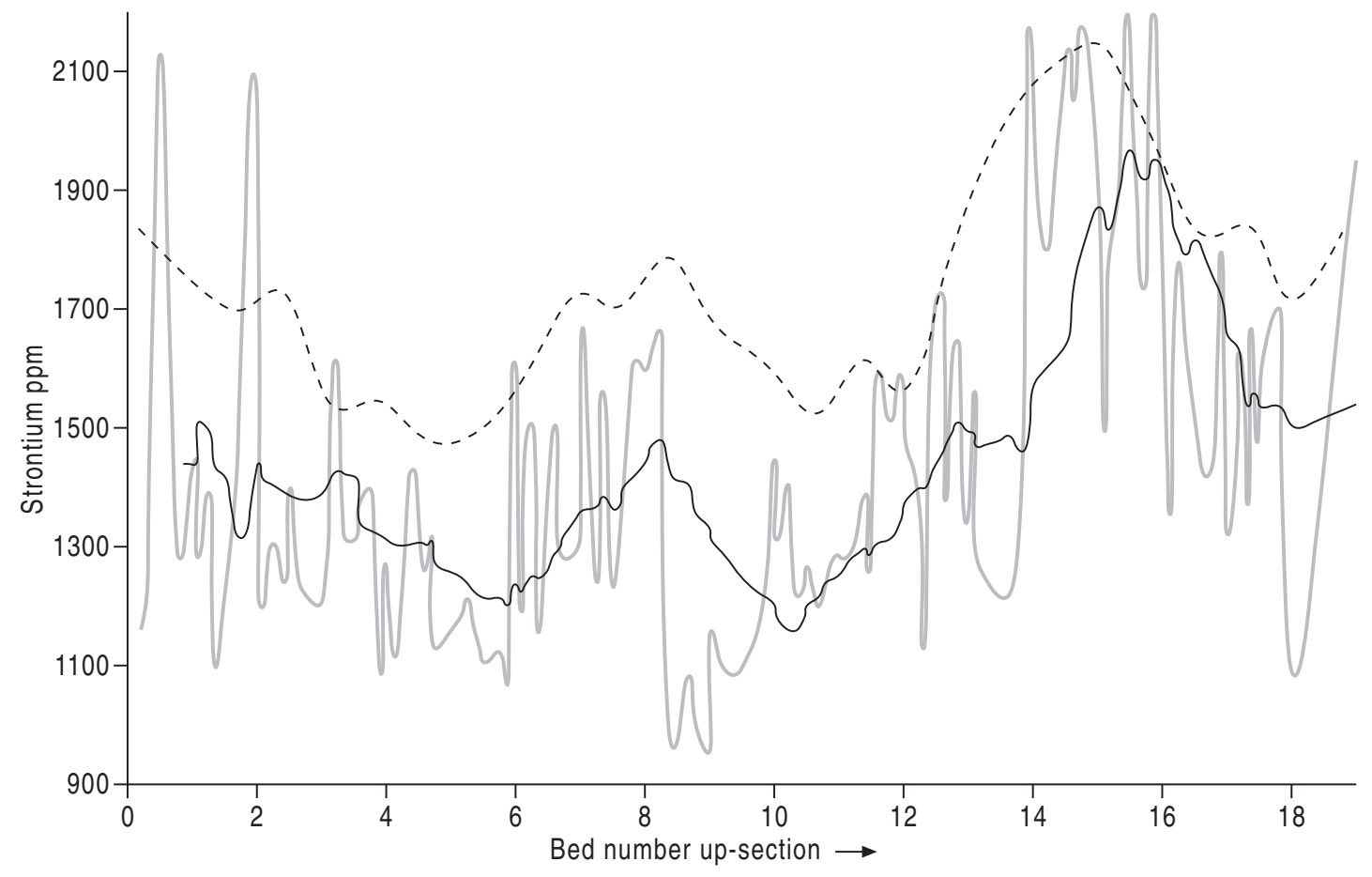

Figure 17 


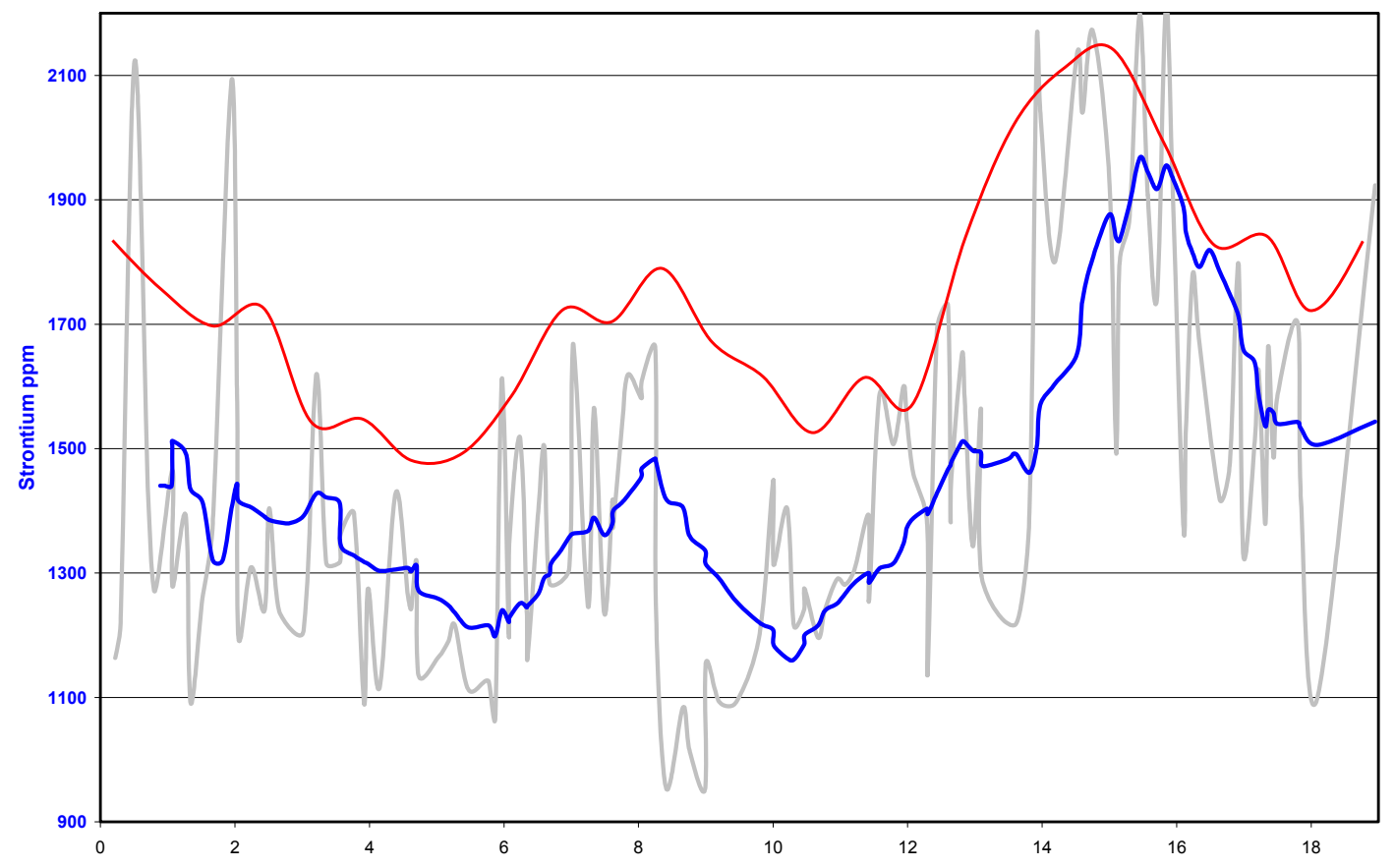

Figure 17 


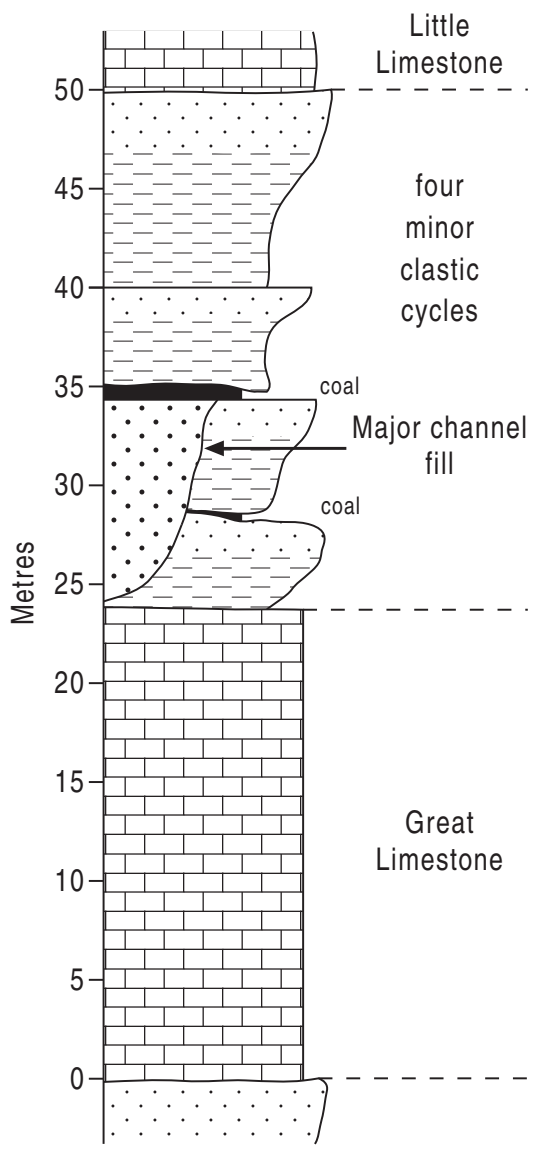

Figure 18 


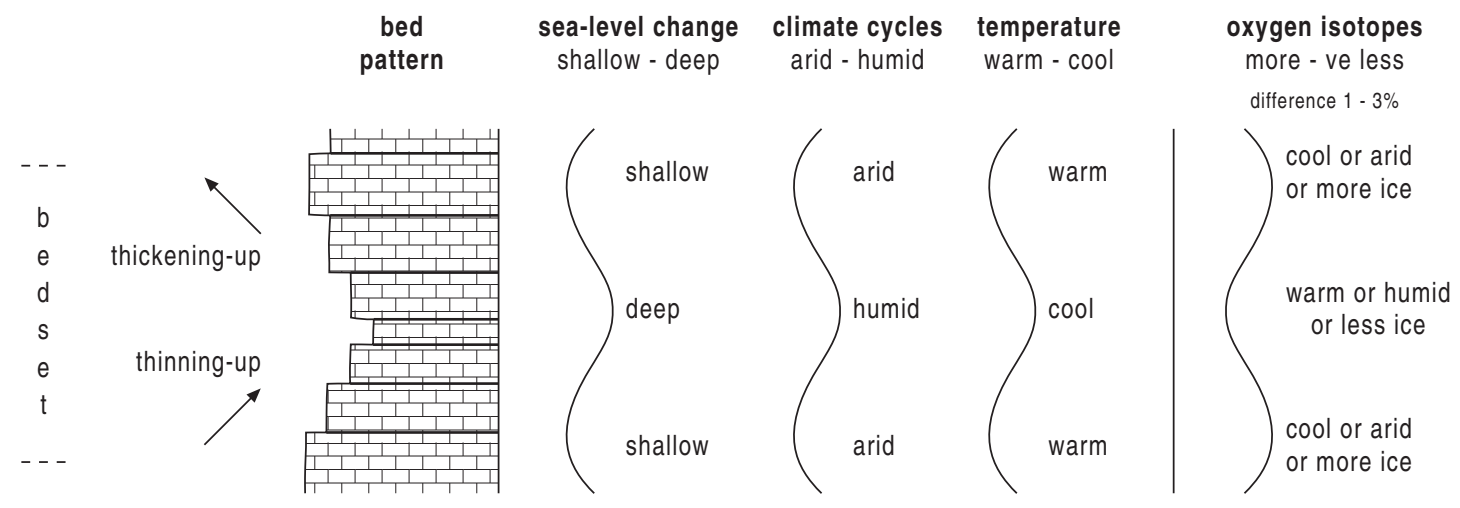

Figure 19 


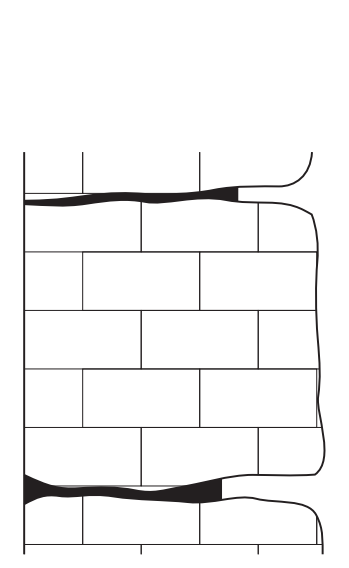

oxygen isotopes

more -.-.- less

negative

Controls on bed deposition

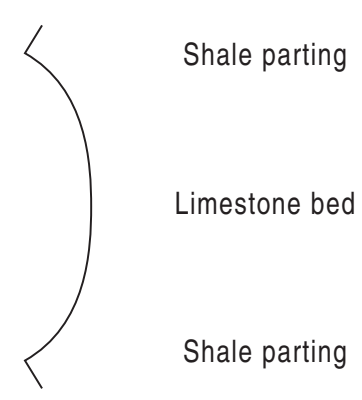

sea-level

climate

temperature

rise

humid

$\mathrm{cool}$

fall

arid

warm

Figure 20 


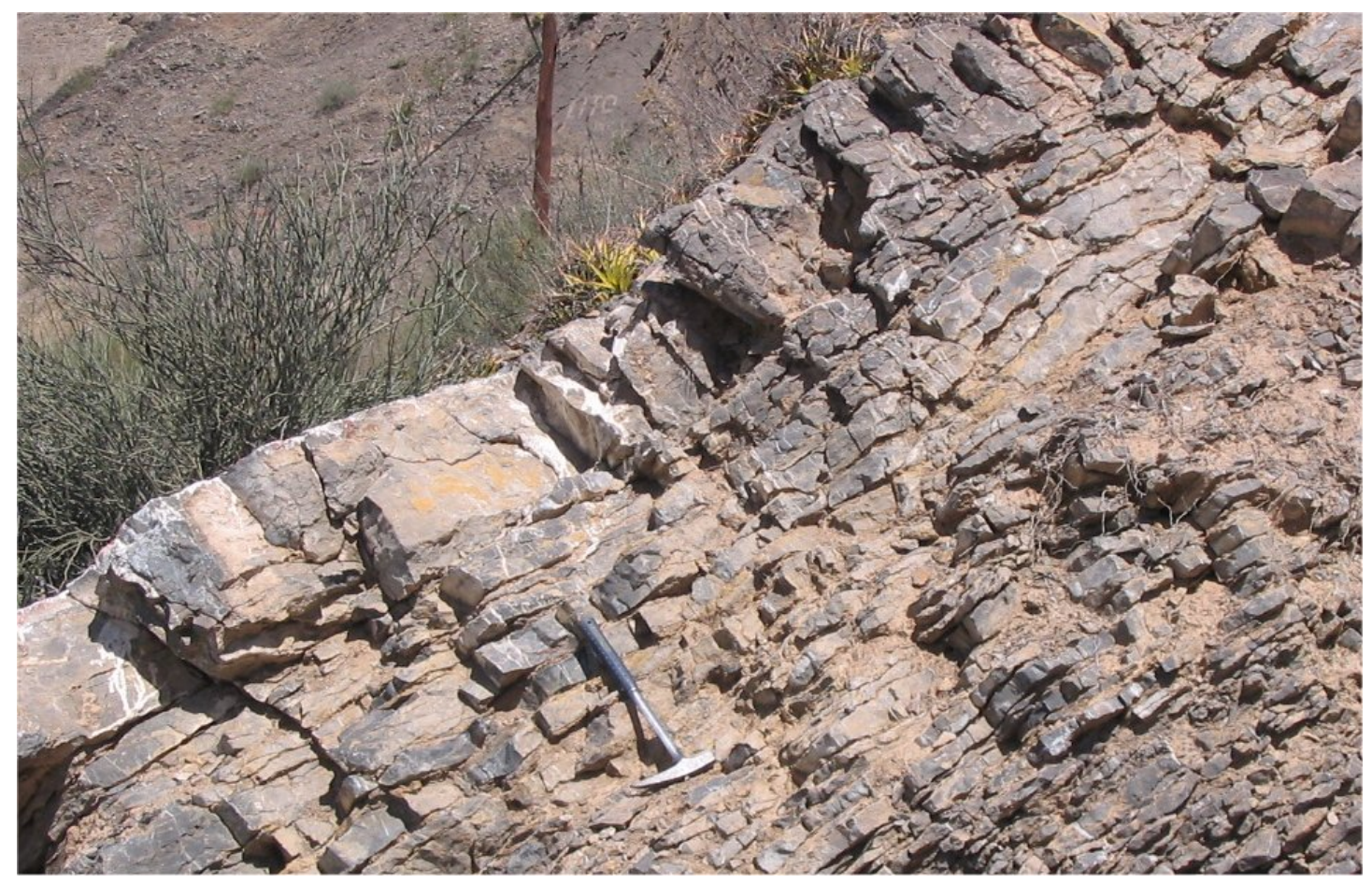

Figure 21 